Article

\title{
Mechanism of Water Oxidation Catalyzed by a Dinuclear Ruthenium Complex Bridged by Anthraquinone
}

\author{
Tohru Wada ${ }^{1, *}$, Shunsuke Nishimura ${ }^{1}$, Taro Mochizuki ${ }^{1}$, Tomohiro Ando ${ }^{1}$ and Yuji Miyazato ${ }^{2}$ \\ 1 Department of Chemistry, College of Science and Research Center for Smart Molecules, Rikkyo University, \\ 3-34-1, Nishi-Ikebukuro, Toshima-ku, Tokyo 171-8501, Japan; sh1_btpyan_m2h3@ezweb.ne.jp (S.N.); \\ enjoyfootball_0414@yahoo.co.jp (T.M.); 15lb009c@rikkyo.ac.jp (T.A.) \\ 2 School of Science and Engineering, Tokyo Denki University, Hatoyama, Hiki-gun, Saitama 350-0394, Japan; \\ miyazato@mail.dendai.ac.jp \\ * Correspondence: twada@rikkyo.ac.jp; Tel.: +81-3-3985-2373
}

Academic Editor: Yurii V. Geletii

Received: 5 January 2017; Accepted: 6 February 2017; Published: 10 February 2017

\begin{abstract}
We synthesized 1,8-bis $\left(2,2^{\prime}: 6^{\prime}, 2^{\prime \prime}\right.$-terpyrid-4'-yl)anthraquinone (btpyaq) as a new dimerizing ligand and determined its single crystal structure by $\mathrm{X}$-ray analysis. The dinuclear Ruthenium complex $\left[\mathrm{Ru}_{2}(\mu-\mathrm{Cl})(\text { bpy })_{2}\right.$ (btpyaq) $]\left(\mathrm{BF}_{4}\right)_{3}\left([3]\left(\mathrm{BF}_{4}\right)_{3}\right.$, bpy $=2,2^{\prime}$-bipyridine $)$ was used as a catalyst for water oxidation to oxygen with $\left(\mathrm{NH}_{4}\right)_{2}\left[\mathrm{Ce}\left(\mathrm{NO}_{3}\right)_{6}\right]$ as the oxidant (turnover numbers $=248$ ). The initial reaction rate of oxygen evolution was directly proportional to the concentration of the catalyst and independent of the oxidant concentration. The cyclic voltammogram of [3] $\left(\mathrm{BF}_{4}\right)_{3}$ in water at $\mathrm{pH} 1.3$ showed an irreversible catalytic current above $+1.6 \mathrm{~V}$ (vs. SCE), with two quasi-reversible waves and one irreversible wave at $E_{1 / 2}=+0.62,+0.82 \mathrm{~V}$, and $E_{\mathrm{pa}}=+1.13 \mathrm{~V}$, respectively. UV-vis and Raman spectra of $[3]\left(\mathrm{BF}_{4}\right)_{3}$ with controlled-potential electrolysis at $+1.40 \mathrm{~V}$ revealed that $[\mathrm{Ru}(\mathrm{IV})=\mathrm{O}$ $\mathrm{O}=\mathrm{Ru}(\mathrm{IV})]^{4+}$ is stable under electrolysis conditions. [Ru(III), $\left.\mathrm{Ru}(\mathrm{II})\right]$ species are recovered after dissociation of an oxygen molecule from the active species in the catalytic cycle. These results clearly indicate that an $\mathrm{O}-\mathrm{O}$ bond is formed via $[\mathrm{Ru}(\mathrm{V})=\mathrm{O} O=\mathrm{Ru}(\mathrm{IV})]^{5+}$.
\end{abstract}

Keywords: water oxidation; Ruthenium complex; mechanism; Raman spectroscopy; electrochemistry

\section{Introduction}

Artificial photosynthesis is the conversion process from solar to chemical energy and includes carbon dioxide, proton, and nitrogen reduction by visible light irradiation, with water as the electron source [1-10]. Four-electron water oxidation to dioxygen is, therefore, an essential process for artificial photosynthesis, while there are several types of reduction processes. Water oxidation is the so-called "bottleneck of artificial photosynthesis" because of the simultaneous transfer of four electrons and the relatively high equilibrium electrode potential (1.23 V vs. NHE at $\mathrm{pH} 0$ ) [11]. Many complexes containing $\mathrm{Ru}, \mathrm{Mn}, \mathrm{Ir}, \mathrm{Fe}, \mathrm{Cu}$, and $\mathrm{Co}$ have been reported as molecular water oxidation catalysts [12-29]. One advantage of using molecular catalysts is the possibility of elucidating the reaction mechanism. A mechanism involving $\mathrm{O}-\mathrm{O}$ bond formation from two water molecules is an especially attractive aspect from the viewpoint of fundamental chemistry. For Ru-complex catalysts, the $\mathrm{O}-\mathrm{O}$ bond formation mechanisms proposed by different research groups can be roughly classified into two types: (1) nucleophilic-attack mechanisms; and (2) homo-coupling mechanisms (Scheme 1) [17,21,30-34]. In both mechanisms, high-valent $\mathrm{Ru}=\mathrm{O}$ species $(\mathrm{Ru}(\mathrm{IV})$ or $\mathrm{Ru}(\mathrm{V}))$ are produced by proton-coupled electron transfer (PCET) reactions of a complex catalyst [35-39]. In the nucleophilic-attack mechanism, water or a hydroxide nucleophile attacks an electron-deficient oxo ligand of high-valent $\mathrm{Ru}=\mathrm{O}$ 
to form an $\mathrm{O}-\mathrm{O}$ bond. Meyer et al. proposed a nucleophilic-attack mechanism, wherein an $\mathrm{H}_{2} \mathrm{O}$ molecule attacks the oxo ligand of $\mathrm{Ru}(\mathrm{V})=\mathrm{O}$ for water oxidation catalyzed by mono-nuclear Ruthenium complexes, $\left[\mathrm{Ru}(\operatorname{trpy})(\mathrm{bpm})\left(\mathrm{OH}_{2}\right)\right]^{2+}$ (trpy: 2,2':6',2"-terpyridine; bmp: 2,2'-bipyrimidine) and $\left[\mathrm{Ru}(\mathrm{Mebimpy})(\mathrm{bpy})\left(\mathrm{OH}_{2}\right)\right]^{2+}$ (Mebimpy: 2,6-bis(1-methylbenzimidazol-2-yl)pyridine; bpy: $2,2^{\prime}$-bipyridine) [40]. Significant electron-deficiency of the oxo ligand in the high-valent $\mathrm{Ru}=\mathrm{O}$ is necessary to form the $\mathrm{O}-\mathrm{O}$ bond because of the low nucleophilicity of water under acidic conditions. Recently, a mechanism involving nucleophilic attack of $\mathrm{OH}^{-}$to $\mathrm{Ru}(\mathrm{IV})=\mathrm{O}$ in neutral and alkaline media was reported [41]. In contrast, radical species, $\mathrm{Ru}(\mathrm{III})-\mathrm{O}^{\bullet}$ and $\mathrm{Ru}(\mathrm{IV})-\mathrm{O}^{\bullet}$, which are in resonance with structures $\mathrm{Ru}(\mathrm{IV})=\mathrm{O}$ and $\mathrm{Ru}(\mathrm{V})=\mathrm{O}$, respectively, couple with each other to form $\mathrm{O}-\mathrm{O}$ bonds in a homo-coupling mechanism. In particular, the homo-coupling mechanism is advantageous for dinuclear Ruthenium complexes containing a rigid bridging ligand. Llobet has reported a dinuclear Ruthenium complex, $\left\{\left[\mathrm{Ru}(\operatorname{trpy})\left(\mathrm{H}_{2} \mathrm{O}\right)\right]_{2}(\mu \text {-bpp) }\}^{3+}\right.$ (bpp: 2,6-bis(pyridyl)pyrazolate), as a water oxidation catalyst, with an intramolecular coupling mechanism based on the results of isotope experiments for this catalytic system [42]. For a Ru(bda) (bda: 2,2'-bipyridine-6,6'-dicarboxylato) catalyst series by Sun, non-covalent interactions between the axial ligands of two catalyst molecules effectively promoted the intermolecular coupling of $\mathrm{Ru}(\mathrm{V})=\mathrm{O}$ species [43-45]. Recently, a strong donor ligand in trans position to an oxo ligand was found to contribute with $\mathrm{M}^{(n-1)+}-\mathrm{O}^{\bullet}$ species to the resonance structure of high-valent transition metal oxo complexes $M^{n+}=\mathrm{O}[46,47]$. A strong electron-donor ligand generally shifts the redox potential of a complex to negative values [48]. To catalyze water oxidation with a small overpotential, a homo-coupling mechanism would therefore be more favorable than a nucleophilic-attack mechanism.

$$
\mathrm{Ru}(\mathrm{II})-\mathrm{OH}_{2} \frac{-2 \mathrm{e}^{-}}{-2 \mathrm{H}^{+}} \mathrm{Ru}(\mathrm{IV})=\mathrm{O} \stackrel{-\mathrm{e}^{-}}{\longrightarrow} \mathrm{Ru}(\mathrm{V})=\mathrm{O}
$$

(1) Water nucleophilic-attack mechanism

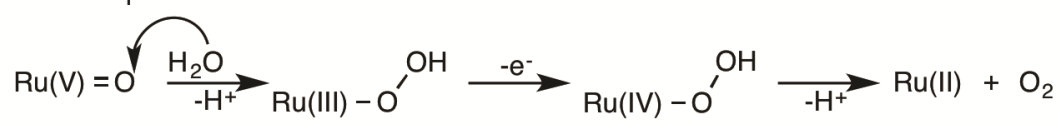

(2)Homo-coupling mechanism

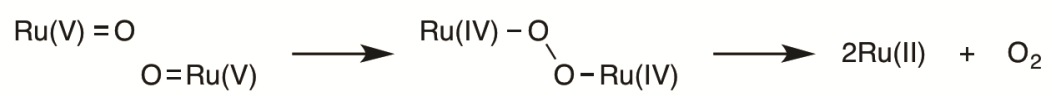

Scheme 1. Possible mechanisms of water oxidation.

We reported the dinuclear Ruthenium complexes $[1]\left(\mathrm{SbF}_{6}\right)_{2}$ and $[2]\left(\mathrm{BF}_{4}\right)_{3}$ bridged by 1,8-bis $\left(2,2^{\prime}: 6^{\prime}, 2^{\prime \prime}\right.$-terpyrid-4'-yl)anthracene (btpyan), which effectively catalyzed the chemical and electrochemical water oxidation (Scheme 2) [49-54]. A distinctive feature of the $\mathrm{Ru}_{2}$ (btpyan) complexes is a face-to-face structure comprising btpyan, which presents the advantage of an $\mathrm{O}-\mathrm{O}$ bond being formed via intramolecular coupling of two high-valent $\mathrm{Ru}=\mathrm{O}$ moieties. DFT calculations of $\left.\left[\mathrm{Ru}_{2}(\mathrm{OH})_{2}\left(t-\mathrm{Bu}_{2} \mathrm{q}\right)_{2} \text { (btpyan) }\right]^{2+}\left(t-\mathrm{Bu}_{2} \mathrm{q}: 3,6 \text {-di-tert-butyl-1,2-benzoquinone, [1 }\right]^{2+}\right)$ by Muckerman [49,52], Yamaguchi [55-57], and Baik [58] revealed intramolecular homo-coupling mechanisms. Resonance Raman spectra of the chemically and electrochemically oxidized forms of $\left[\mathrm{Ru}_{2}(\mu-\mathrm{Cl})(\mathrm{bpy})_{2}(\mathrm{btpyan})\right]^{3+}$ $\left([2]^{3+}\right.$, bpy $=2,2^{\prime}$-bipyridine) showed an $\mathrm{O}-\mathrm{O}$ vibration band at $824 \mathrm{~cm}^{-1}$, which was shifted to $780 \mathrm{~cm}^{-1}$ when chemical and electrochemical oxidation of $[2]^{3+}$ was conducted in $\mathrm{H}_{2}{ }^{18} \mathrm{O}[49,50]$. Therefore, water oxidation catalyzed by $[2]^{3+}$ proceeds via intramolecular coupling of two high-valent $\mathrm{Ru}=\mathrm{O}$ species. However, the details of high-valent $\mathrm{Ru}=\mathrm{O}$ coupling are not yet clear. In particular, the oxidation states of the active species in $\mathrm{Ru}=\mathrm{O}$ coupling are not yet clear.

In this paper, we prepared a new bridging ligand, 1,8-bis $\left(2,2^{\prime}: 6^{\prime}, 2^{\prime \prime}\right.$-terpyrid-4'-yl)anthraquinone (btpyaq), and a dinuclear Ruthenium complex bridged by btpyaq, $\left[\mathrm{Ru}_{2}(\mu-\mathrm{Cl})(\mathrm{bpy})_{2}(\mathrm{btpyaq})\right]\left(\mathrm{BF}_{4}\right)_{3}$ $\left([3]\left(\mathrm{BF}_{4}\right)_{3}\right.$, Scheme 2). The details of the water oxidation mechanism and the influence of the slight 
structural differences between the anthracene and anthraquinone bridging ligands were investigated by spectroelectrochemical measurements and kinetic analysis.

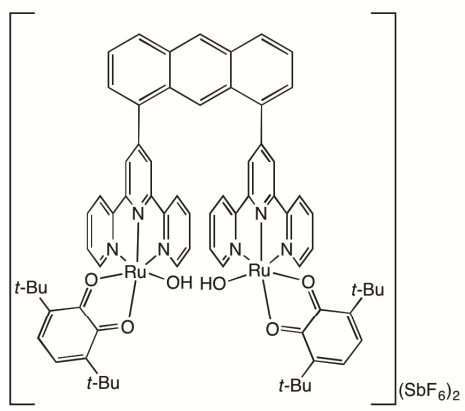

$[1]\left(\mathrm{SbF}_{6}\right)_{2}$

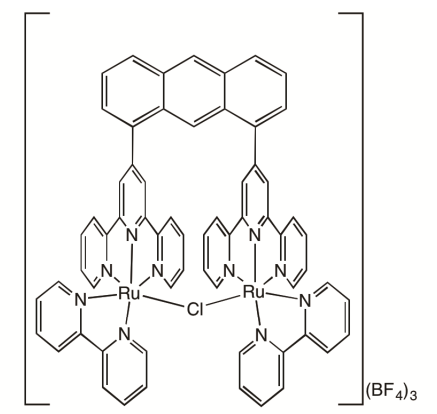

$[2]\left(\mathrm{BF}_{4}\right)_{3}$

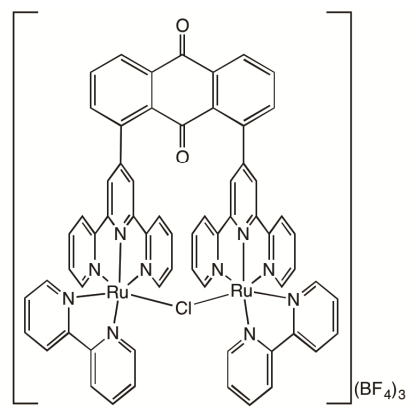

$[3]\left(\mathrm{BF}_{4}\right)_{3}$

Scheme 2. Dinuclear ruthenium complex catalysts for water oxidation.

\section{Results and Discussion}

\subsection{Syntheses of Bis(terpyridyl)anthraquinone and Dinuclear Ruthenium Complexes}

A new bridging ligand, btpyaq, was prepared via a synthetic pathway (Scheme 3) similar to that for btpyan [51]. The reaction of 1,8-dichloroanthraquinone with two equiv. of bis(neopentylglycolato) diboron in the presence of $8 \mathrm{~mol} \%$ of $\mathrm{Pd}_{2}(\mathrm{dba})_{3}(\mathrm{dba}=$ dibenzylideneacetone) and Xphos (2-dicyclohexylphosphino-2', $4^{\prime}, 6^{\prime}$-triisopropylbiphenyl) gave 1,8-anthraquinonediboronic acid bis(neopentylglycol) ether in $84 \%$ yield. Compared to the synthesis of 1,8-anthracenediboronic acid bis(neopentylglycol) ether, large amounts of the catalyst were required in the preparation of 1,8-anthraquinonediboronic acid bis(neopentylglycol) ether because of the steric repulsion between the $\mathrm{O}$ and $\mathrm{Cl}$ atoms of 1,8-dichloroanthraquinone. The neopentylglycol ether was smoothly hydrolyzed to produce anthraquinone-1,8-diboronic acid, from which a Miyaura-Suzuki cross coupling reaction with $4^{\prime}-\{$ (trifluoromethylsulfonyl)oxy $\}-2,2^{\prime}: 4^{\prime}, 2^{\prime \prime}$-terpyridine in the presence of $\mathrm{Pd}\left(\mathrm{PPh}_{3}\right)_{4}(10 \mathrm{~mol} \%)$ afforded btpyan in $80 \%$ yield.<smiles>O=C1c2cccc(Cl)c2C(=O)c2cccc(Cl)c21</smiles>

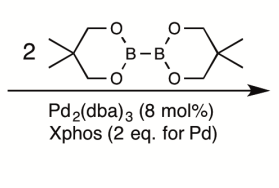<smiles>CC1(C)COB(c2cccc3c2C(=O)c2c(B4OCC(C)(C)CO4)cccc2C3=O)OC1</smiles><smiles>O=C1c2cccc(B(O)O)c2C(=O)c2c(B(O)O)cccc21</smiles><smiles>Cc1cccc(-c2cc(O)cc(-c3cccc(O)c3)n2)n1</smiles>

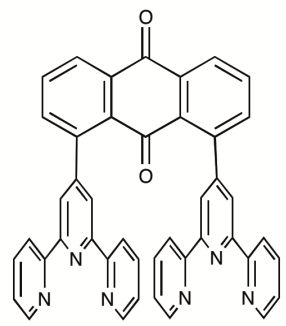

btpyaq

Scheme 3. Synthesis scheme for btpyaq.

Suitable crystals of btpyaq for X-ray analysis were obtained from a benzene solution (Figure 1). The dihedral angles between two terpyridine moieties and the anthraquinone skeleton are 65.59 and $59.85^{\circ}$. The distance between $\mathrm{N}(2)$ and $\mathrm{N}(5)$ of the terpyridines is $7.061 \AA$, whereas that between 
the carbon atoms at 1,8-positions of anthraquinone is $5.077 \AA$, as the steric repulsion of the $\mathrm{O}(2)$ of anthraquinone lengthens the distance between the two terpyridine moieties. This structural feature of btpyaq differs from that of the anthracene analog, btpyan, in which the two terpyridines are close to each other by $\pi$-stacking interactions [53].

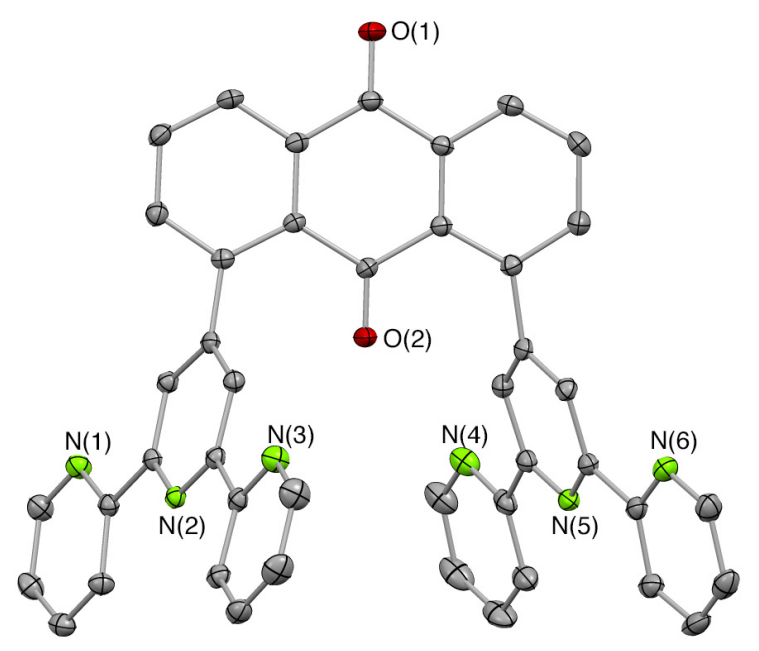

Figure 1. Crystal structure of btpyaq (50\% probability thermal ellipsoids). Hydrogen atoms are omitted for clarity.

Reaction of btpyaq and two equivalents of $\mathrm{RuCl}_{3} \cdot 3 \mathrm{H}_{2} \mathrm{O}$ afforded $\left[\mathrm{Ru}_{2} \mathrm{Cl}_{6}\right.$ (btpyaq)]. $\left[\mathrm{Ru}_{2} \mathrm{Cl}_{2} \text { (bpy) }\right)_{2}$ (btpyaq)] $\left(\mathrm{SbF}_{6}\right)_{2}$ was prepared by the reaction of $\left[\mathrm{Ru}_{2} \mathrm{Cl}_{6}\right.$ (btpyaq)] with two equivalents of the bpy ligand in the presence of $\mathrm{NEt}_{3}$ and purified using chromatographic techniques. The dinuclear Ruthenium complex $\left[\mathrm{Ru}_{2}(\mu-\mathrm{Cl})(\mathrm{bpy})_{2}(\right.$ btpyaq $\left.)\right]\left(\mathrm{BF}_{4}\right)_{3}\left([3]\left(\mathrm{BF}_{4}\right)_{3}\right)$ was prepared by $\mathrm{Cl}^{-}$abstraction reaction of the dichlorido complex, $\left[\mathrm{Ru}_{2} \mathrm{Cl}_{2}(\mathrm{bpy})_{2}(\right.$ btpyaq) $]\left(\mathrm{SbF}_{6}\right)_{2}$, with $\mathrm{AgBF}_{4}$ (Scheme 4$)$. The distance between the two Ruthenium(II) atoms bridged by a single $\mathrm{Cl}^{-}$is typically within $5.2 \AA$ and is shorter than that between $N(2)$ and $N(4)$ in the single crystal of btpyaq (Figure 1). This means that btpyaq has structural flexibility, and the distance between the two Ruthenium atoms is able to change from ca. 5 to $7 \AA$.

$$
\text { btpyaq } \stackrel{2 \mathrm{RuCl}_{3} \cdot 3 \mathrm{H}_{2} \mathrm{O}}{\longrightarrow}\left[\mathrm{Ru}_{2} \mathrm{Cl}_{6}(\text { btpyaq })\right] \stackrel{2 \text { bpy, } \mathrm{Et}_{3} \mathrm{~N} \text { (excess) }}{\mathrm{NaSbF}_{6}}
$$

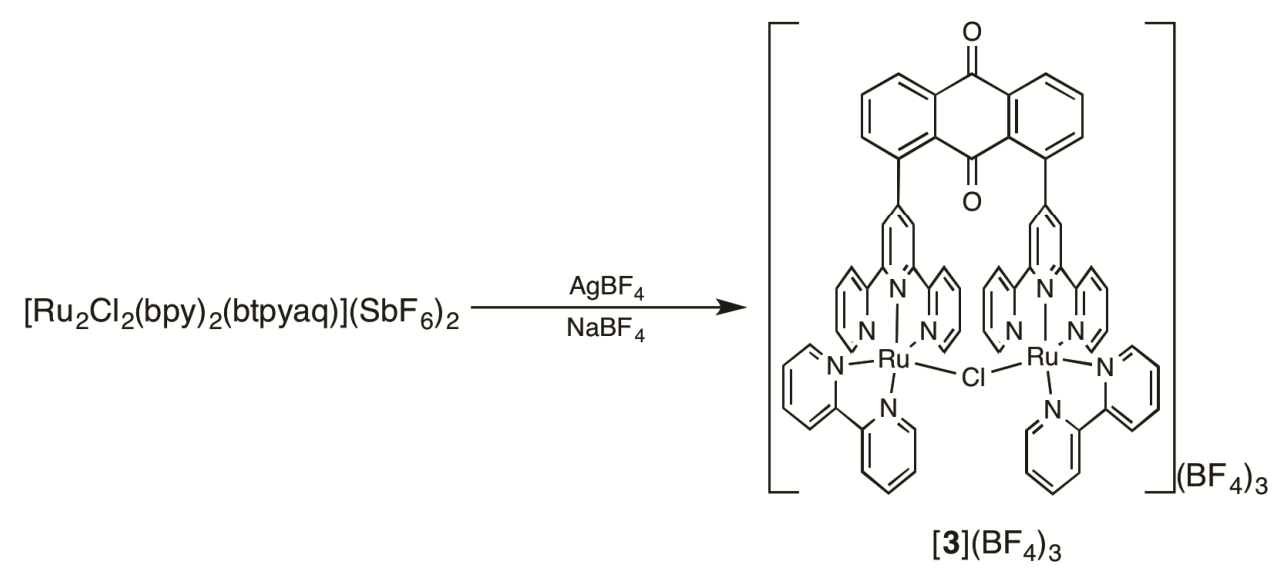

Scheme 4. Synthesis scheme of $\left[\mathrm{Ru}_{2}(\mu-\mathrm{Cl})(\mathrm{bpy})_{2}(\mathrm{btpyaq})\right]\left(\mathrm{BF}_{4}\right)_{3}\left([3]\left(\mathrm{BF}_{4}\right)_{3}\right)$. 


\subsection{Chemical Water Oxidation}

To an aqueous solution at $\mathrm{pH} 1.0$ containing $\left(\mathrm{NH}_{4}\right)_{2}\left[\mathrm{Ce}\left(\mathrm{NO}_{3}\right)_{6}\right](1.00 \mathrm{mmol})$ as the oxidant was added a trifluoroethanol solution of the Ruthenium complex catalyst $(1.0 \mu \mathrm{mol})$ at $293 \mathrm{~K}$. After $30 \mathrm{~h}$, [2] $\left(\mathrm{BF}_{4}\right)_{3}$ and [3] $\left(\mathrm{BF}_{4}\right)_{3}$ evolved $238 \mu \mathrm{mol}$ and $248 \mu \mathrm{mol}$ of oxygen ( $\mathrm{TON}=238$ and 248), respectively (Figure 2). The conversion with $\left(\mathrm{NH}_{4}\right)_{2}\left[\mathrm{Ce}\left(\mathrm{NO}_{3}\right)_{6}\right]$ as the oxidant was $95 \%\left([2]\left(\mathrm{BF}_{4}\right)_{3}\right)$ and $99 \%$ $\left([3]\left(\mathrm{BF}_{4}\right)_{3}\right)$, respectively. When [3] $\left(\mathrm{BF}_{4}\right)_{3}$ was used as the catalyst, most of the oxidant in the solution was consumed within $10 \mathrm{~h}$. In fact, the initial TOF of [3] $\left(\mathrm{BF}_{4}\right)_{3}\left(1.3 \times 10^{-2} \mathrm{~s}^{-1}\right)$ was higher than that of [2] $\left(\mathrm{BF}_{4}\right)_{3}\left(0.97 \times 10^{-2} \mathrm{~s}^{-1}\right)$.

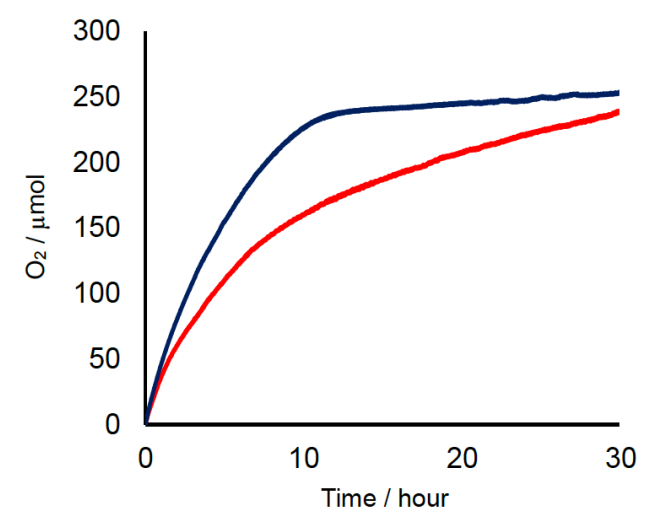

Figure 2. Oxygen evolved from water at $\mathrm{pH} 1.0$ (adjusted by $\mathrm{HNO}_{3}$ ) catalyzed by the Ruthenium complexes $\left(1.00 \mu \mathrm{mol},[2]\left(\mathrm{BF}_{4}\right)_{3}\right.$, red line; [3] $\left(\mathrm{BF}_{4}\right)_{3}$, black line) with $\left(\mathrm{NH}_{4}\right)_{2}\left[\mathrm{Ce}\left(\mathrm{NO}_{3}\right)_{6}\right](1.00 \mathrm{mmol})$.

When $[3]\left(\mathrm{BF}_{4}\right)_{3}$ was used as the catalyst, the initial reaction rate was directly proportional to the concentration of the catalyst and independent of the oxidant concentration (Figure 3A,B, respectively). Thus, the reaction does not proceed via intermolecular coupling of two catalyst molecules. Sakai and Masaoka proposed a mechanism involving $\mathrm{O}-\mathrm{O}$ formation through the coupling of $\mathrm{Ru}=\mathrm{O}$ and $\mathrm{Ce}(\mathrm{IV})-\mathrm{OH}$ as the typical oxidant for water oxidation. If the rate-determining step in the catalytic cycle is the coupling of $\mathrm{Ru}=\mathrm{O}$ and $\mathrm{Ce}(\mathrm{IV})-\mathrm{OH}$, the reaction rate of water oxidation is directly proportional to the $\mathrm{Ce}(\mathrm{IV})$ concentration [59-61]. In our catalytic system, $\mathrm{Ce}(\mathrm{IV})$ does not participate in the rate-determining step of the catalytic cycle.
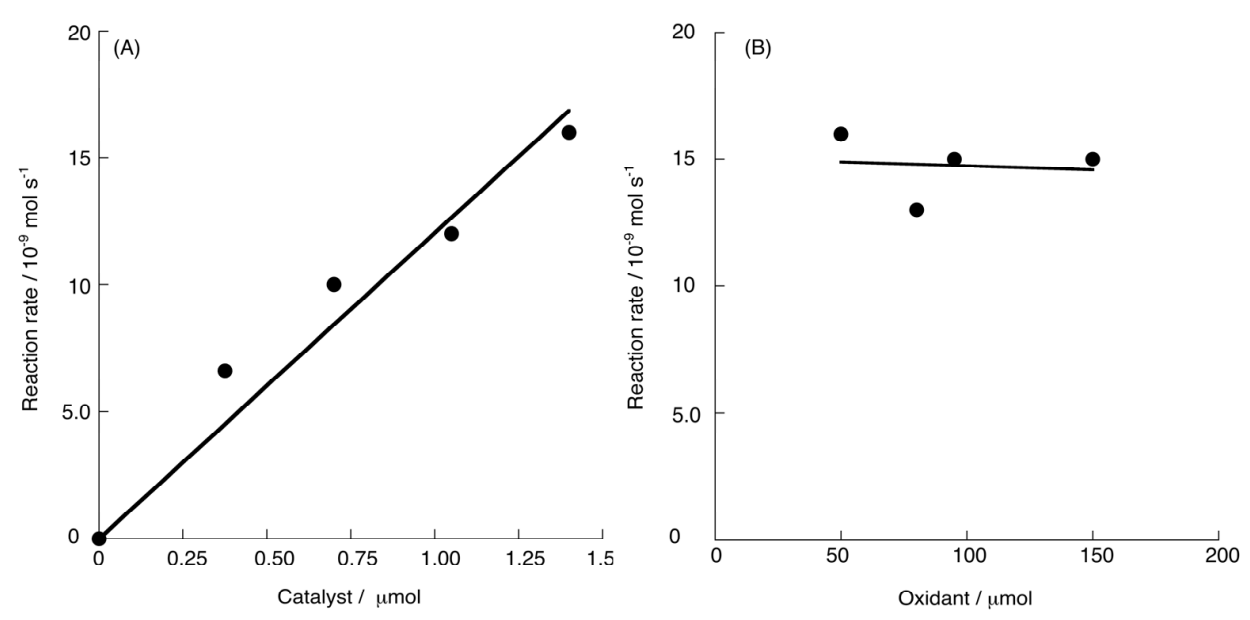

Figure 3. Plots of initial reaction rates for oxygen evolution with [3] $\left(\mathrm{BF}_{4}\right)_{3}:(\mathrm{A})$ as a function of amounts of $[3]\left(\mathrm{BF}_{4}\right)_{3}(\mu \mathrm{mol})$ in $5.0 \mathrm{~mL}$ of $\mathrm{pH} 1.0$ water (adjusted by $\left.\mathrm{HNO}_{3}\right)$ containing $\left(\mathrm{NH}_{4}\right)_{2}\left[\mathrm{Ce}\left(\mathrm{NO}_{3}\right)_{6}\right]$ $(50 \mu \mathrm{mol})$ at $293 \mathrm{~K}$; and $(\mathbf{B})$ as a function of amounts of oxidant $\left(\left(\mathrm{NH}_{4}\right)_{2}\left[\mathrm{Ce}\left(\mathrm{NO}_{3}\right)_{6}\right]\right)$ in the presence of [3] $\left(\mathrm{BF}_{4}\right)_{3}(1.4 \mu \mathrm{mol})$ in $5.0 \mathrm{~mL}$ of $\mathrm{pH} 1.0$ water (adjusted by $\left.\mathrm{HNO}_{3}\right)$ at $293 \mathrm{~K}$. 


\subsection{Redox Behavior of $[3]\left(\mathrm{BF}_{4}\right)_{3}$}

The cyclic voltammogram $(\mathrm{CV})$ of an aqueous solution of $[3]\left(\mathrm{BF}_{4}\right)_{3}$ at $\mathrm{pH} 1.3$ shows two quasi-reversible redox waves at $E_{1 / 2}=+0.62$ and $+0.82 \mathrm{~V}$ (vs. SCE, Figure 4). On the basis of the rest potential of $[3]\left(\mathrm{BF}_{4}\right)_{3}, E_{\text {rest }}=+0.53 \mathrm{~V}$, these redox waves are assigned to $[\mathrm{Ru}(\mathrm{III})-\mathrm{Cl}-\mathrm{Ru}(\mathrm{II})]^{3+} /[\mathrm{Ru}(\mathrm{II})-\mathrm{Cl}-\mathrm{Ru}(\mathrm{III})]^{4+}$ and $[\mathrm{Ru}(\mathrm{II})-\mathrm{Cl}-\mathrm{Ru}(\mathrm{III})]^{4+} /[\mathrm{Ru}(\mathrm{III})-\mathrm{Cl}-\mathrm{Ru}(\mathrm{III})]^{5+}$, respectively. The irreversible oxidation wave at $E_{\mathrm{pa}}=+1.13 \mathrm{~V}$ would correspond to the oxidation of $[\mathrm{Ru}(\mathrm{III})-\mathrm{Cl}-\mathrm{Ru}(\mathrm{III})]^{5+}$, accompanied by dissociation of $\mathrm{Cl}^{-}$(vide infra). Above $+1.5 \mathrm{~V}$, a large catalytic wave arising from water oxidation is observed. In $\mathrm{CF}_{3} \mathrm{CH}_{2} \mathrm{OH}$, the $[\mathrm{Ru}(\mathrm{II})-\mathrm{Cl}-\mathrm{Ru}(\mathrm{II})]^{3+} /[\mathrm{Ru}(\mathrm{II})-\mathrm{Cl}-\mathrm{Ru}(\mathrm{III})]^{4+}$ and $[\mathrm{Ru}(\mathrm{II})-\mathrm{Cl}-\mathrm{Ru}(\mathrm{III})]^{4+} /[\mathrm{Ru}(\mathrm{III})-\mathrm{Cl}-\mathrm{Ru}(\mathrm{III})]^{5+}$ redox waves are observed at +0.91 and $1.18 \mathrm{~V}$, respectively, with a two-electron reduction wave of anthraquinone at $-0.32 \mathrm{~V}$ (Figure S1).

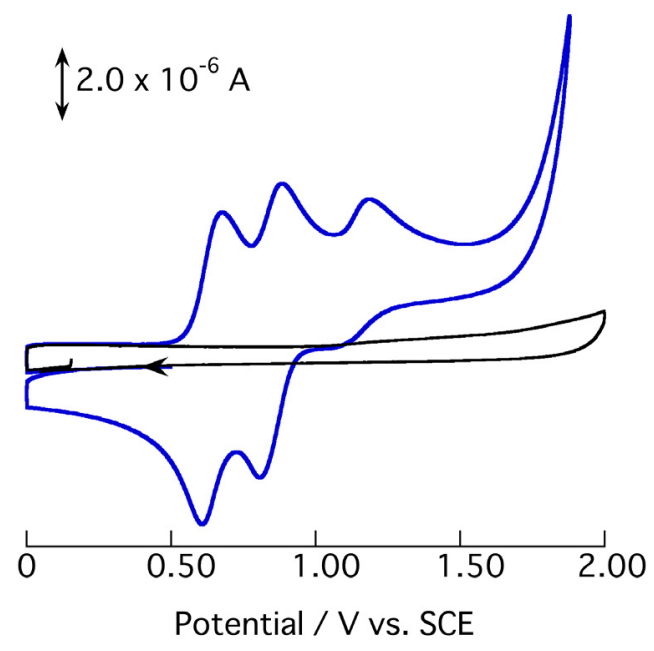

Figure 4. Cyclic voltammogram of $[3]\left(\mathrm{BF}_{4}\right)_{3}$ in aqueous solution at $\mathrm{pH} 1.3$ (blue line). The solution $\mathrm{pH}$ was adjusted by addition of $\mathrm{HNO}_{3}$ to the solution containing $0.2 \mathrm{mmol} \cdot \mathrm{L}^{-1}$ of $[3]\left(\mathrm{BF}_{4}\right)_{3}$ and $100 \mathrm{mmol} \cdot \mathrm{L}^{-1}$ of $\mathrm{NaNO}_{3}$ as the electrolyte. Scan: $50 \mathrm{mV} \cdot \mathrm{s}^{-1}$; temperature: $298 \mathrm{~K}$; working electrode: ITO; counter electrode: Pt wire, reference electrode: SCE. The arrow indicates the rest potential and scanning direction. Black line indicates $\mathrm{CV}$ of the solution without $[3]\left(\mathrm{BF}_{4}\right)_{3}$ under the same conditions.

To assign the redox waves in the CV (Figure 4), we conducted UV-vis spectral measurements of [3] $\left(\mathrm{BF}_{4}\right)_{3}$ with controlled-potential electrolysis. An aqueous solution of [3] $\left(\mathrm{BF}_{4}\right)_{3}$ at $\mathrm{pH} 1.0$ exhibited an absorption band at $485 \mathrm{~nm}$ arising from the metal-to-ligand charge transfer (MLCT) of the $\mathrm{Ru}$ (II)(bpy) moieties (Figure 5A). When the solution was electrolyzed at $+0.81 \mathrm{~V}$, which is the potential between the two quasi-reversible redox waves of the CV (Figure 4), the absorbance of the $485 \mathrm{~nm}$ band decreased to almost half that before electrolysis (Figure 5A). Re-reduction at $+0.53 \mathrm{~V}$ resulted in the reversible recovery of the spectrum of $[3]\left(\mathrm{BF}_{4}\right)_{3}$; this result is consistent with the assignment of the wave at $+0.62 \mathrm{~V}$ to a reversible $[\mathrm{Ru}(\mathrm{II})-\mathrm{Cl}-\mathrm{Ru}(\mathrm{II})]^{3+} /[\mathrm{Ru}(\mathrm{II})-\mathrm{Cl}-\mathrm{Ru}(\mathrm{III})]^{4+}$ redox reaction. Further oxidation of the solution at $+1.04 \mathrm{~V}$ changed the color of the solution from dark brown to dark green, and two-step spectral changes were clearly observed. First, the $485 \mathrm{~nm}$ band was reduced (blue lines in Figure 5B). Thereafter, the intensity of the $686 \mathrm{~nm}$ band gradually increased with a decrease in the $485 \mathrm{~nm}$ band (orange lines in Figure 5B). These spectral changes indicate that the one-electron oxidation of $[\mathrm{Ru}(\mathrm{II})-\mathrm{Cl}-\mathrm{Ru}(\mathrm{III})]^{4+}$ to $[\mathrm{Ru}(\mathrm{III})-\mathrm{Cl}-\mathrm{Ru}(\mathrm{III})]^{5+}$ is followed by cleavage of the $\mathrm{Ru}-\mathrm{Cl}$ bond and coordination of $\mathrm{OH}^{-}$to give $[\mathrm{Ru}(\mathrm{III})-\mathrm{OH} \mathrm{Cl}-\mathrm{Ru}(\mathrm{III})]^{4+}$, which is smoothly one-electron oxidized with a deprotonation to $[\mathrm{Ru}(\mathrm{IV})=\mathrm{O} \mathrm{Cl}-\mathrm{Ru}(\mathrm{III})]^{4+}$. The corresponding redox wave at $+0.62 \mathrm{~V}$ in the $\mathrm{CV}$ is quasi-reversible as $\mathrm{Ru}-\mathrm{Cl}$ bond cleavage and coordination of water to $\mathrm{Ru}$ are quite slow compared to the CV scanning rate (Figure 4). The intensity of the $686 \mathrm{~nm}$ band arising from $\mathrm{Ru}(\mathrm{IV})=\mathrm{O}$ is increased upon further oxidation of the solution at $+1.40 \mathrm{~V}$ (spectra $\mathrm{C}$ of Figure 5). $[\mathrm{Ru}(\mathrm{IV})=\mathrm{O} \mathrm{O}=\mathrm{Ru}(\mathrm{IV})]^{4+}$ is produced via one-electron oxidation of the $\mathrm{Cl}-\mathrm{Ru}(\mathrm{III})$ moiety with dissociation $\mathrm{Cf}^{-}$and association 
of $\mathrm{H}_{2} \mathrm{O}$, followed by double deprotonation. Surprisingly, the $686 \mathrm{~nm}$ band remained unaltered for over $24 \mathrm{~h}$. This means that $[\mathrm{Ru}(\mathrm{IV})=\mathrm{O} \mathrm{O}=\mathrm{Ru}(\mathrm{IV})]^{4+}$ is relatively stable in acidic water at room temperature and is not the active species in the water oxidation cycle. Oxidation at $+1.60 \mathrm{~V}$, at which water oxidation proceeds, decreased the intensity of the $686 \mathrm{~nm}$ band (Figure 5D). After electrolysis was stopped, the MLCT band of $\mathrm{Ru}(\mathrm{II})$ (bpy) at $486 \mathrm{~nm}$ gradually increased and the absorbance became half that in the initial spectrum (Figure 5E). This result suggests that the $[\mathrm{Ru}(\mathrm{II}) \mathrm{Ru}(\mathrm{III})]$ species is recovered by releasing oxygen from the active species, which is expected to be the $[\mathrm{Ru}(\mathrm{III})-\mathrm{O}-\mathrm{O}-\mathrm{Ru}(\mathrm{IV})]^{5+}$ dimer generated by intramolecular coupling of $[\mathrm{Ru}(\mathrm{IV})=\mathrm{O} \mathrm{O}=\mathrm{Ru}(\mathrm{V})]^{5+}$. In fact, the $\mathrm{CV}$ of the solution after electrolysis at $+1.60 \mathrm{~V}$ showed a rest potential at $+0.72 \mathrm{~V}$ between two redox waves (Figure S2).
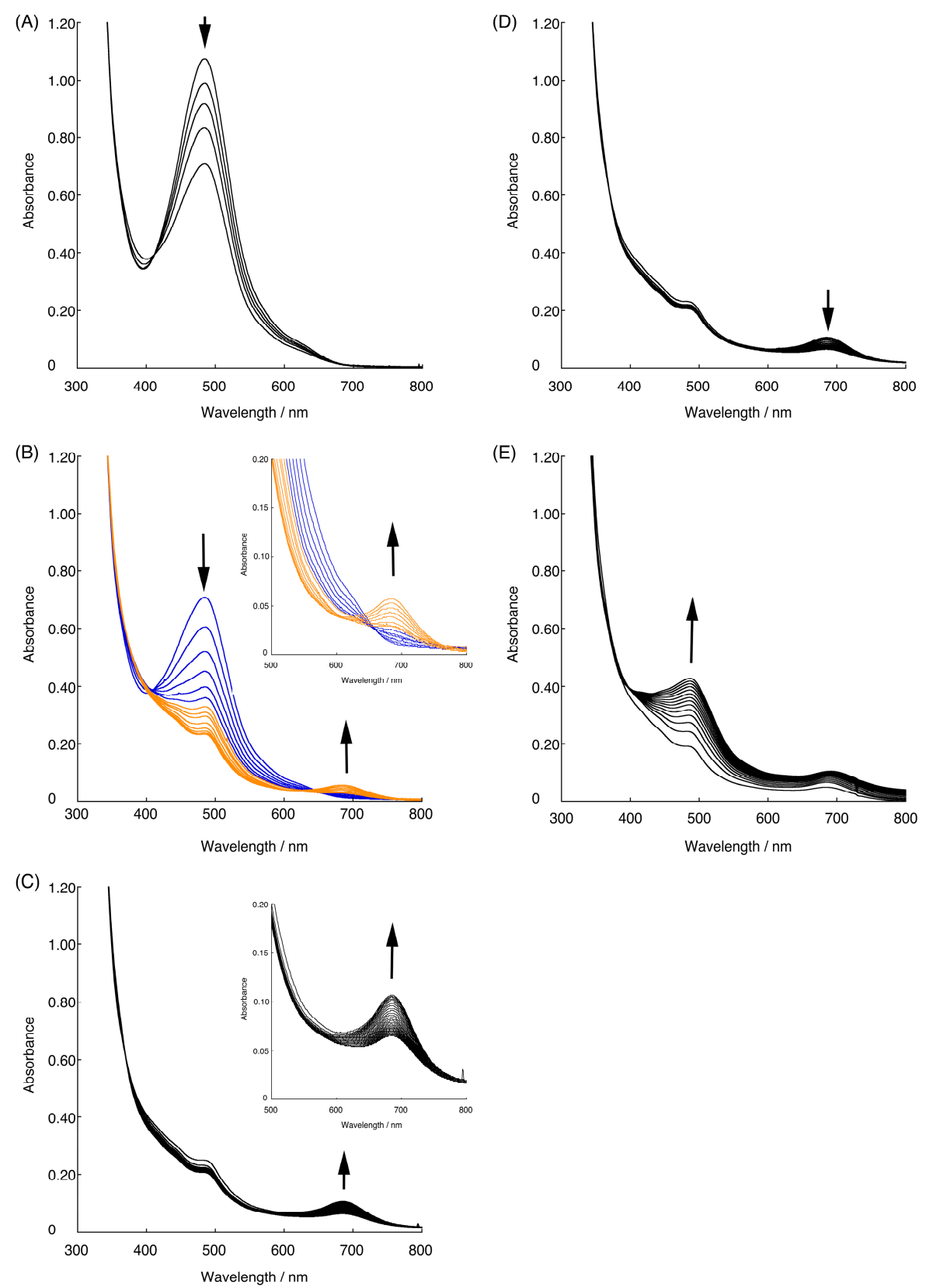

Figure 5. UV-vis spectral changes of an aqueous solution of $[3]\left(\mathrm{BF}_{4}\right)_{3}$ at $\mathrm{pH} 1.3$ by potentiostatic electrolysis at: $+0.81 \mathrm{~V}(\mathbf{A}) ;+1.04 \mathrm{~V}(\mathbf{B}) ;+1.40 \mathrm{~V}(\mathbf{C}) ;+1.60 \mathrm{~V}(\mathbf{D})$; and after electrolysis was stopped (E). Insets of $(\mathbf{B}, \mathbf{C})$ are the enlarged spectra from $500 \mathrm{~nm}$ to $800 \mathrm{~nm}$. 


\subsection{Raman Spectra of the Intermediate}

Raman spectroscopy is a powerful method for the assignment of intermediate species such as $\mathrm{Ru}=\mathrm{O}$ and $\mathrm{Ru}-\mathrm{O}-\mathrm{O}-\mathrm{Ru}$, in water oxidation catalytic cycles. The Raman spectra of the green solutions after electrochemical oxidation of ${ }^{16} \mathrm{O}$-water and ${ }^{18} \mathrm{O}$-water solutions by $[3]\left(\mathrm{BF}_{4}\right)_{3}$ at $+1.40 \mathrm{~V}$, irradiated with a $532 \mathrm{~nm}$ laser, showed bands at 794 and $754 \mathrm{~cm}^{-1}$, respectively (Figure 6). The difference between the two bands is $-40 \mathrm{~cm}^{-1}$, which is consistent with the calculated value for $\mathrm{Ru}=\mathrm{O}\left(-41 \mathrm{~cm}^{-1}\right)$. Values of 818 and $780 \mathrm{~cm}^{-1}$ were reported by Hurst et al. for the Raman bands of $\mathrm{Ru}(\mathrm{V})={ }^{16} \mathrm{O}$ and $\mathrm{Ru}(\mathrm{V})={ }^{18} \mathrm{O}$, respectively, in cis,cis-[(bpy) $\left.{ }_{2} \mathrm{Ru}(\mathrm{O})\right]_{2} \mathrm{O}^{4+}[62]$. Therefore, the $[\mathrm{Ru}(\mathrm{IV})=\mathrm{O} \mathrm{O}=\mathrm{Ru}(\mathrm{IV})]$ observed by Raman spectroscopy is not the active species. An $\mathrm{O}-\mathrm{O}$ bond is expected to be formed at higher oxidation states of the catalyst, which is consistent with the CV results (Figure 4) and UV-vis spectral measurements with controlled-potential electrolysis (Figure 5).
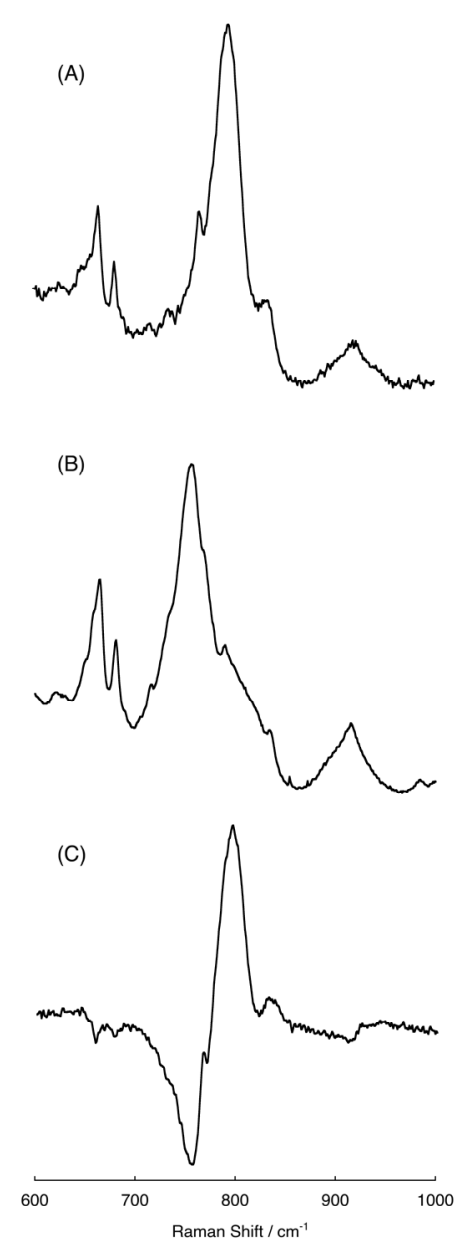

Figure 6. Raman spectra of [3] $\left(\mathrm{BF}_{4}\right)_{3}$ in: ${ }^{16} \mathrm{O}$-water $(\mathbf{A})$; and ${ }^{18} \mathrm{O}$-water $(\mathbf{B})$ at $\mathrm{pH} 1.0$, adjusted with $\mathrm{HNO}_{3}$, after electrochemical oxidation at $+1.40 \mathrm{~V}$, and the difference spectrum $(\mathbf{C})$ between spectra A and $\mathrm{B}$.

In contrast, we already reported that the Raman bands of the species formed by oxidation of [2] $\left(\mathrm{BF}_{4}\right)_{3}$ under the same conditions are observed at 442 and $824 \mathrm{~cm}^{-1}$, which are shifted to 426 and $780 \mathrm{~cm}^{-1}$, respectively, when the same electrolysis is conducted in $\mathrm{H}_{2}{ }^{18} \mathrm{O}$. These bands are assigned to $\mathrm{Ru}-\mathrm{O}$ and $\mathrm{O}-\mathrm{O}$ vibrations because the isotope shift values $\left(-16\right.$ and $\left.-44 \mathrm{~cm}^{-1}\right)$ are identical to the calculated value. The rate-determining step in the catalytic cycle is not the $\mathrm{O}-\mathrm{O}$ bond formation, but the release of $\mathrm{O}_{2}$ from the $[\mathrm{Ru}-\mathrm{O}-\mathrm{O}-\mathrm{Ru}]$ species. When [3] $\left(\mathrm{BF}_{4}\right)_{3}$ was used as the catalyst, the $[\mathrm{Ru}-\mathrm{O}-\mathrm{O}-\mathrm{Ru}]$ species was not observed by Raman spectral measurements. These results clearly 
indicate that evolution of $\mathrm{O}_{2}$ from $[\mathrm{Ru}-\mathrm{O}-\mathrm{O}-\mathrm{Ru}]$ is not the rate-determining step in the water oxidation by [3] $\left(\mathrm{BF}_{4}\right)_{3}$. According to the crystal structure of btpyaq (Figure 1), [3] $\left(\mathrm{BF}_{4}\right)_{3}$ displays higher flexibility of the $\mathrm{Ru}-\mathrm{Ru}$ distance compared to the anthracene analog, [2] $\left(\mathrm{BF}_{4}\right)_{3}$. The structural flexibility of [3] $\left(\mathrm{BF}_{4}\right)_{3}$ would accelerate the release of an $\mathrm{O}_{2}$ molecule from the $[\mathrm{Ru}-\mathrm{O}-\mathrm{O}-\mathrm{Ru}]$ species and changes the rate-determining step in the catalytic cycle.

\subsection{Catalytic Mechanism of Water Oxidation}

Based on the above results, we propose possible mechanisms for the water oxidation catalyzed by $[3]\left(\mathrm{BF}_{4}\right)_{3}$. Sequential one-electron oxidations of $[3]\left(\mathrm{BF}_{4}\right)_{3}$ produce $[\mathrm{Ru}(\mathrm{III})-\mathrm{Cl}-\mathrm{Ru}(\mathrm{III})]^{5+}$, to which $\mathrm{OH}^{-}$is slowly added. The resulting $[\mathrm{Ru}(\mathrm{III})-\mathrm{OH} \mathrm{Cl}-\mathrm{Ru}(\mathrm{III})]^{4+}$ undergoes oxidation coupled with deprotonation (PCET reaction) at the same potential of the second oxidation of $[3]\left(\mathrm{BF}_{4}\right)_{3}$. $[\mathrm{Ru}(\mathrm{IV})=\mathrm{O}$ $\mathrm{O}=\mathrm{Ru}(\mathrm{IV})]^{4+}$ is produced by PCET reaction of $[\mathrm{Ru}(\mathrm{IV})=\mathrm{O} \mathrm{Cl}-\mathrm{Ru}(\mathrm{III})]^{4+}$ in the same manner (Scheme 5).

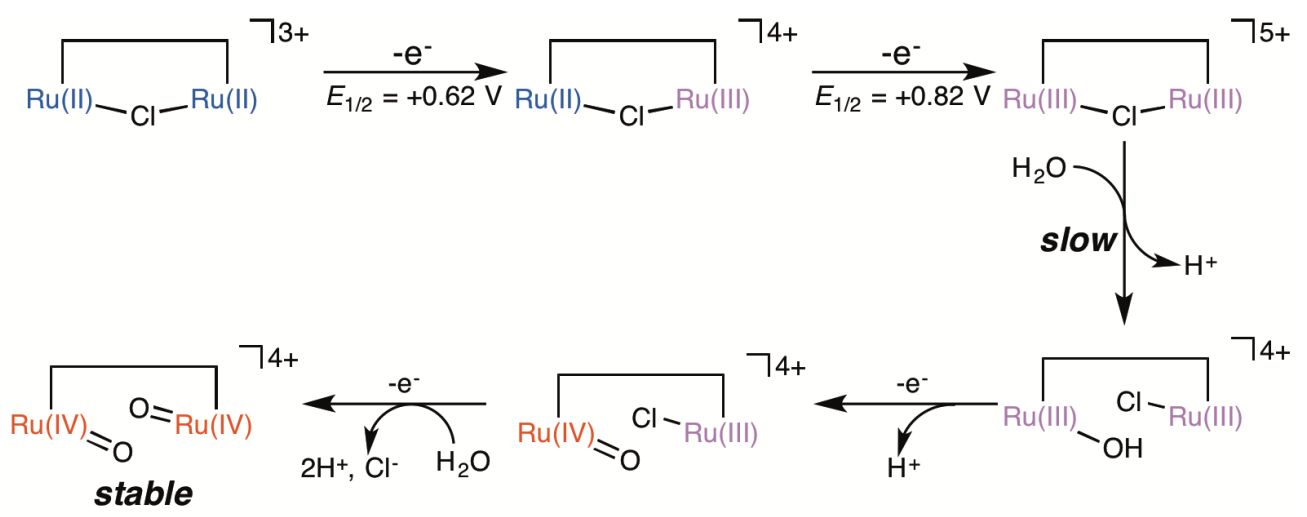

Scheme 5. Mechanism for $\mathrm{Ru}(\mathrm{IV})$ species in the water oxidation catalytic cycle.

For the oxygen evolution mechanism after the production of $[\mathrm{Ru}(\mathrm{IV})=\mathrm{O} \mathrm{O}=\mathrm{Ru}(\mathrm{IV})]^{4+}$, two possibilities cannot be ruled out. From the results of UV-vis and Raman spectral measurements with controlled-potential electrolysis, $[\mathrm{Ru}(\mathrm{IV})=\mathrm{O} \mathrm{O}=\mathrm{Ru}(\mathrm{IV})]^{4+}$ is stable and does not form an $\mathrm{O}-\mathrm{O}$ bond. It is at least necessary that $[\mathrm{Ru}(\mathrm{IV})=\mathrm{O} \mathrm{O}=\mathrm{Ru}(\mathrm{IV})]^{4+}$ loses an electron and is oxidized to $[\mathrm{Ru}(\mathrm{IV})=\mathrm{O} \mathrm{O}=\mathrm{Ru}(\mathrm{V})]^{5+}$. There are considerable contributions from the oxo radical species, $\mathrm{Ru}(\mathrm{IV})-\mathrm{O}^{-}$, as a resonance form in the electronic state of $\mathrm{Ru}(\mathrm{V})=\mathrm{O}$. The radical character of $\mathrm{Ru}(\mathrm{IV})-\mathrm{O}^{-}$. induces $[\mathrm{Ru}(\mathrm{IV})=\mathrm{O} \mathrm{O}=\mathrm{Ru}(\mathrm{V})]^{5+}$ to form $[\mathrm{Ru}(\mathrm{III})-\mathrm{O}-\mathrm{O}-\mathrm{Ru}(\mathrm{IV})]^{5+}$. An oxygen molecule is released by substitution of two water molecules to give $[\mathrm{Ru}(\mathrm{II})-\mathrm{OH} \mathrm{HO}-\mathrm{Ru}(\mathrm{III})]^{3+}$, as observed by $\mathrm{CV}$ and $\mathrm{UV}$-vis spectral measurements (intramolecular coupling mechanism, Scheme 6).

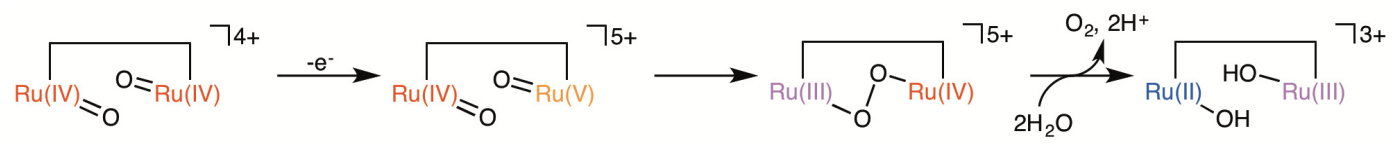

Scheme 6. Intramolecular coupling mechanism.

The other possibility is a nucleophilic-attack mechanism (Scheme 7), similar to that proposed for the water oxidation catalyzed by cis, cis- $\left[(\mathrm{bpy})_{2} \mathrm{Ru}(\mathrm{O})\right]_{2} \mathrm{O}^{4+}[63-66]$. A water molecule nucleophilically attacks the oxo ligand of $\mathrm{Ru}(\mathrm{V})=\mathrm{O}$ more easily than that of $\mathrm{Ru}(\mathrm{IV})=\mathrm{O}$ in $[\mathrm{Ru}(\mathrm{IV})=\mathrm{O} \mathrm{O}=\mathrm{Ru}(\mathrm{V})]^{5+}$ in acidic media. The $\mathrm{Ru}(\mathrm{IV})=\mathrm{O}$ moiety acts as a base and redox center when an oxygen molecule is released from the peroxo complex. 


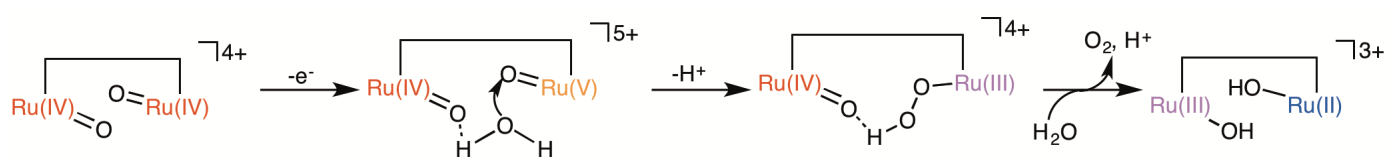

Scheme 7. Nucleophilic-attack mechanism.

No direct experimental evidence is yet available for clarifying the mechanism of this catalytic system. Water oxidation catalyzed by the anthracene analog, [2] $\left(\mathrm{BF}_{4}\right)_{3}$, however, clearly proceeds via an intramolecular coupling mechanism [50]. The anthraquinone ligand of [3] $\left(\mathrm{BF}_{4}\right)_{3}$ is sufficiently flexible to form a Cl-bridged structure while there is steric hindrance between the two terpyridines and the oxygen atom. Therefore, there is a higher probability for an intramolecular coupling mechanism than for a nucleophilic-attack mechanism. The details of the mechanism are now under investigation in our laboratory.

\section{Materials and Methods}

\subsection{Materials}

Bis(neopentylglycolato)diboron was purchased from Wako Pure Chemical Industries, Ltd. (Osaka, Japan), and 2-dicyclohexylphosphino-2', 4', $6^{\prime}$-triisopropylbiphenyl (Xphos) and $\mathrm{Pd}\left(\mathrm{PPh}_{3}\right)_{4}$ were purchased from Sigma-Aldrich Chemical Co. (St. Louis, MO, USA). $\mathrm{RuCl}_{3} \cdot n \mathrm{H}_{2} \mathrm{O}$ was purchased from Furuya Metal Co., Ltd. (Tokyo, Japan), 2,2'-bipyridine and $\mathrm{AgBF}_{4}$ were purchased from Tokyo Chemical Industry Co., Ltd. (Tokyo, Japan), and 1,8-dichloroanthraquinone and $\left(\mathrm{NH}_{4}\right)_{2}\left[\mathrm{Ce}\left(\mathrm{NO}_{3}\right)_{6}\right]$ were purchased from Kanto Chemical Co. Inc. (Tokyo, Japan). All other reagents were purchased from Kanto Chemical Co. Inc. and were used without further purification. $\operatorname{Pd}_{2}(\mathrm{dba})_{3}$ [67], $4^{\prime}$-[(trifluoromethylsulfonyl)oxy]-2,2':6',2"'-terpyridine [68], and $\left[\mathrm{Ru}_{2}(\mu-\mathrm{Cl})(\mathrm{bpy})_{2}(\mathrm{btpyan})\right]\left(\mathrm{BF}_{4}\right)$ $\left([2]\left(\mathrm{BF}_{4}\right)\right)[50]$ were synthesized according to previously reported procedures.

\subsection{Instrumentation}

UV-vis-NIR spectra were recorded on a Shimadzu UV-1800 UV-vis-NIR scanning spectrophotometer (Shimazu Corp., Kyoto, Japan). ESI-MS spectra were measured on an AccuTOF LC-plus JMS-T100L (JEOL Ltd., Tokyo, Japan). Elemental analyses were performed with a Vario Micro Cube from Elementar Analysensysteme GmbH (Langenseldold, Germany). ${ }^{1} \mathrm{H}$ NMR spectra were recorded on a BRUKER AVANCE $400 \mathrm{MHz}$ NMR spectrometer (Bruker Corp., Blerica, MA, USA). Cyclic voltammetry (CV) was performed on an ALS/Chi model 720-electrochemical analyzer (ALS Corp. Ltd., Tokyo, Japan). Raman spectra were measured with an NRS-5100 Laser Raman Spectrometer with a Nd:YVO 4 laser (532 nm) (JASCO Corp. Tokyo, Japam). Electrolysis was carried out using a Hokuto Denko HA-501 potentiostat (Hokuto Denko Corp., Tokyo, Japan).

\subsection{Syntheses}

\subsubsection{1,8-Bis(neopentylglycolatoboryl)anthraquinone}

Bis(neopentylglycolato)diborone (468 mg, $2.1 \mathrm{mmol}), \mathrm{Pd}_{2}(\mathrm{dba})_{3}(117 \mathrm{mg}, 0.13 \mathrm{mmol}, 8.0 \mathrm{~mol} \%$ ), 2-dicyclohexylphosphino-2' $4^{\prime}, 6^{\prime}$-triisopropylbiphenyl (253 mg, $0.53 \mathrm{mmol}, 2.0$ equiv. for $\mathrm{Pd}$ ), and $\mathrm{NaOAc}(861 \mathrm{~g}, 10 \mathrm{mmol})$ in anhydrous 1,4-dioxane $(80 \mathrm{~mL})$ were added to a Schlenk tube (Sugiyama-gen Corp. Ltd., Tokyo, Japan), which was heated at $60^{\circ} \mathrm{C}$ in vacuo for $15 \mathrm{~min}$. After the Schlenk tube was cooled to room temperature and purged with $\mathrm{N}_{2}$, anhydrous 1,4-dioxane $(15 \mathrm{~mL})$ was added to the Schlenk tube. Then, 1,8-dichloroanthraquinone ( $235 \mathrm{mg}, 0.95 \mathrm{mmol})$ was added to the solution, which was stirred at $90{ }^{\circ} \mathrm{C}$ for $24 \mathrm{~h}$ under $\mathrm{N}_{2}$. The solution color changed from reddish brown to yellow during the reaction. The reaction mixture was evaporated to dryness. Toluene $(20 \mathrm{~mL})$ was added to the flask and the thus formed colorless precipitate was removed from the solution by 
filtration. The volume of the yellow toluene solution was reduced in vacuo to ca. $5 \mathrm{~mL}$. Hexane $(10 \mathrm{~mL})$ was carefully layered on the toluene solution, which was allowed to stand for $1 \mathrm{~d}$. Yellow needle crystals were obtained by filtration. Yield: $324 \mathrm{~g}(84 \%)$. ${ }^{1} \mathrm{H}-\mathrm{NMR}\left(400 \mathrm{MHz}\right.$, in $\left.\mathrm{CDCl}_{3}\right)$ : $\partial$ (ppm) 8.26 $\left(\mathrm{dd}, 2 \mathrm{H}, J^{1}=7.3 \mathrm{~Hz}, J^{2}=1.5 \mathrm{~Hz}\right.$, anthraquinone), $7.79\left(\mathrm{dd}, J^{1}=7.3 \mathrm{~Hz}, J^{2}=1.5 \mathrm{~Hz}\right.$, anthraquinone), $7.75\left(\mathrm{dd}, 2 \mathrm{H}, J^{1}=J^{2}=7.3 \mathrm{~Hz}\right.$ anthraquinone), $3.86\left(\mathrm{~s}, 8 \mathrm{H}, \mathrm{CH}_{2}\right), 1.21\left(\mathrm{~s}, 12 \mathrm{H}, \mathrm{CH}_{3}\right)$. Anal. Calc. for $\mathrm{C}_{24} \mathrm{H}_{26} \mathrm{O}_{6} \mathrm{~B}_{2}$ (432.09), C 66.71, H 6.07; found, C 66.62, H 6.18.

\subsubsection{Anthraquinone-1,8-diboronic Acid}

A suspension of 1,8-bis(neopentylglycolatoboryl)anthraquinone $(1.2 \mathrm{~g}, 2.8 \mathrm{mmol})$ in $\mathrm{HCl}$ $\left(6.0 \mathrm{~mol} \cdot \mathrm{L}^{-1}, 10 \mathrm{~mL}\right)$ was stirred for $24 \mathrm{~h}$ at room temperature. A pale-yellow powder precipitated form the solution was separated by filtration, washed with $\mathrm{CHCl}_{3}$, and dried in vacuo. Yield: $0.58 \mathrm{~g}$ (62\%). ${ }^{1} \mathrm{H}-\mathrm{NMR}\left(400 \mathrm{MHz}\right.$, in DMSO- $\left.d_{6}\right): \partial(\mathrm{ppm}) 8.03\left(\mathrm{dd}, 2 \mathrm{H}, J^{1}=7.6 \mathrm{~Hz}, J^{2}=1.4 \mathrm{~Hz}\right.$, anthraquinone), $7.74\left(\mathrm{dd}, 2 \mathrm{H}, J^{1}=J^{2}=7.6 \mathrm{~Hz}\right.$, anthraquinone), $7.70(\mathrm{~s}, 4 \mathrm{H}, \mathrm{OH}), 7.68\left(\mathrm{dd}, 2 \mathrm{H}, J^{1}=7.6 \mathrm{~Hz}, J^{2}=1.4 \mathrm{~Hz}\right.$, anthraquinone). Anal. Calc. for $\mathrm{C}_{14} \mathrm{H}_{10} \mathrm{O}_{6} \mathrm{~B}_{2} \cdot 2 \mathrm{H}_{2} \mathrm{O}$ (331.88), $\mathrm{C} 50.67, \mathrm{H} 4.25$; found, $\mathrm{C} 50.41, \mathrm{H} 4.33$.

\subsubsection{1,8 -Bis $\left(2,2^{\prime}: 6^{\prime}, 2^{\prime \prime}\right.$-terpyrid-4'-yl)anthraquinone (Btpyaq)}

A mixture of anthraquinone-1,8-diboronic acid ( $0.35 \mathrm{~g}, 1.1 \mathrm{mmol}), 4^{\prime}$-[(trifluoromethylsulfonyl)oxy]2,2': $6^{\prime}, 2^{\prime \prime}$-terpyridine (1.0 g, $\left.2.7 \mathrm{mmol}\right), \mathrm{Pd}\left(\mathrm{PPh}_{3}\right)_{4}(0.28 \mathrm{~g}, 0.24 \mathrm{mmol}, 10 \mathrm{~mol} \%)$, and $\mathrm{K}_{2} \mathrm{CO}_{3}(1.3 \mathrm{~g}$, $9.4 \mathrm{mmol})$ in toluene $(60 \mathrm{~mL})$, ethanol $(18 \mathrm{~mL})$, and distilled water $(8.2 \mathrm{~mL})$ was stirred at $90{ }^{\circ} \mathrm{C}$ under $\mathrm{N}_{2}$ for $3 \mathrm{~d}$. After the reaction solution was cooled to room temperature, crude product was precipitated by addition of methanol $(50 \mathrm{~mL})$ to the solution. The crude product was obtained as a gray powder by filtration and dried in vacuo. The pure product was obtained by Soxhlet extraction with $\mathrm{CHCl}_{3}$. Yield: $0.63 \mathrm{~g}(74 \%)$. ${ }^{1} \mathrm{H}-\mathrm{NMR}(400 \mathrm{MHz}$, in $\mathrm{CDCl} 3) \partial$ (ppm) $8.45(\mathrm{~m}, 6 \mathrm{H}$, terpyridine, anthraquinone), $8.42\left(\mathrm{~d}, J=8.0 \mathrm{~Hz}, 4 \mathrm{H}\right.$, terpyridine), $8.23\left(\mathrm{~s}, 4 \mathrm{H}\right.$, terpyridine), $7.79\left(\mathrm{dd}, J^{1}=J^{2}=7.6\right.$ $\mathrm{Hz}, 2 \mathrm{H}$, anthraquinone), $7.70\left(\mathrm{ddd}, J^{1}=J^{2}=8 \mathrm{~Hz}, J^{3}=1.8 \mathrm{~Hz}, 4 \mathrm{H}\right.$, terpyridine), $7.61\left(\mathrm{dd}, J^{1}=7.6 \mathrm{~Hz}\right.$, $J^{2}=1.3 \mathrm{~Hz}, 2 \mathrm{H}$, anthraquinone), $7.16\left(\mathrm{ddd}, J^{1}=8 \mathrm{~Hz}, J^{2}=4.8 \mathrm{~Hz}, J^{3}=1.2 \mathrm{~Hz}, 4 \mathrm{H}\right.$, terpyridine). Anal. Calc. for C46H32Cl2N6O2 (771.70): C 71.60, H 4.18, N 10.89, O 4.77; found: C 70.87, H 3.68, N 11.03. DART-MS: $m / z=671.39\left([\mathrm{M}]+\mathrm{H}^{+}\right)$.

\subsection{4. $\mathrm{Ru}_{2} \mathrm{Cl}_{6}$ (btpyaq)}

An ethanol solution $(120 \mathrm{~mL})$ of $\mathrm{RuCl}_{3} \cdot 3 \mathrm{H}_{2} \mathrm{O}(340 \mathrm{mg}$, $1.30 \mathrm{mmol})$ was refluxed under $\mathrm{N}_{2}$ for $5 \mathrm{~min}$. After the solution was cooled to room temperature, btpyaq ( $300 \mathrm{mg}, 0.45 \mathrm{mmol}$ ) was added to the solution, followed by reflux under $\mathrm{N}_{2}$ for $3 \mathrm{~h}$. The precipitated brown powder was filtered and washed three times with methanol $(20 \mathrm{~mL})$ and acetone $(20 \mathrm{~mL})$, respectively. The product was dried

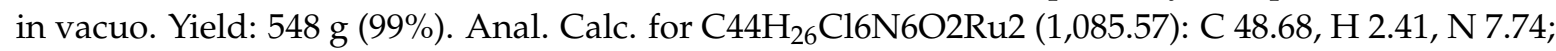
found: C 48.51, H 2.54, N 7.78.

\subsection{5. $\left[\mathrm{Ru}_{2} \mathrm{Cl}_{2}(\text { bpy })_{2}(\right.$ btpyaq $\left.)\right]\left(\mathrm{SbF}_{6}\right)_{2}$}

$\mathrm{Et}_{3} \mathrm{~N}(150 \mu \mathrm{L})$ was added to a suspension of $\left[\mathrm{Ru}_{2} \mathrm{Cl}_{6}\right.$ (btpyaq) $]$ ( $\left.362 \mathrm{mg}, 0.33 \mathrm{mmol}\right), 2,2^{\prime}$-bipyridine (113 mg, $0.72 \mathrm{mmol})$, and $\mathrm{LiCl}(145 \mathrm{~g}, 3.4 \mathrm{mmol})$ in $\mathrm{EtOH}(90 \mathrm{~mL})$ and $\mathrm{H}_{2} \mathrm{O}(25 \mathrm{~mL})$ under $\mathrm{N}_{2}$. The solution was refluxed for $10 \mathrm{~h}$ under $\mathrm{N}_{2}$. A saturated $\mathrm{NaSbF}_{6}$ solution in water $(1 \mathrm{~mL})$ was then added and the resulting mixture evaporated to ca. $10 \mathrm{~mL}$. The crude product was obtained as a brown powder by filtration, dried in vacuo, and separated by column chromatography with Alumina A, akt. I (MP Biomedicals Germany $\mathrm{GmbH}$ ) with $\mathrm{CH}_{2} \mathrm{Cl}_{2} / \mathrm{EtOH}(95 / 5)$ as the eluent. An aqueous solution of $\mathrm{NaSbF}_{6}$ was added to the dark purple fraction. Concentration of the solution under reduced pressure gave a dark purple powder that was then separated by filtration. The pure product was obtained as a dark purple powder by recrystallization from $\mathrm{CH}_{3} \mathrm{CN} /$ diethyl ether and dried in vacuo. Yield: $154 \mathrm{mg}$ (27\%). MS(ESI): $m / z: 628.02$ ([M] ${ }^{2+}$, Calc. 628.05). Anal. Calc. for $\mathrm{C}_{64} \mathrm{H}_{42} \mathrm{C}_{12} \mathrm{~F}_{12} \mathrm{~N}_{10} \mathrm{O}_{2} \mathrm{Ru}_{2} \mathrm{Sb}_{2}$ (1727.65): C 44.49, H2.45, N 8.11; found: C 44.45, H 2.57, N 8.24. 


\subsection{6. $\left[\mathrm{Ru}_{2}(\mu-\mathrm{Cl})(\text { bpy })_{2}(\right.$ btpyaq $\left.)\right]\left(\mathrm{BF}_{4}\right)_{3}\left([3]\left(\mathrm{BF}_{4}\right)_{3}\right)$}

A solution of $\left[\mathrm{Ru}_{2} \mathrm{Cl}_{2}\right.$ (bpy) ${ }_{2}$ (btpyaq) $]\left(\mathrm{SbF}_{6}\right)_{2}(60 \mathrm{mg}, 0.035 \mathrm{mmol}), \mathrm{AgBF}_{4}(28 \mathrm{mg}, 0.13 \mathrm{mmol})$, and $\mathrm{CF}_{3} \mathrm{SO}_{3} \mathrm{H}(3 \mu \mathrm{L}, 0.035 \mathrm{mmol})$ in $\mathrm{CF}_{3} \mathrm{CH}_{2} \mathrm{OH}(25 \mathrm{~mL})$ and $\mathrm{H}_{2} \mathrm{O}(5 \mathrm{~mL})$ was stirred at $65^{\circ} \mathrm{C}$ for $40 \mathrm{~min}$ under $\mathrm{N}_{2}$. The resultant brown solution was filtered to remove $\mathrm{AgCl}$. An aqueous solution of $\mathrm{Me}_{4} \mathrm{NBF}_{4}$ was added to the filtrate, which was evaporated to ca. $3 \mathrm{~mL}$. The dark brown powder was separated by filtration, and the pure product was obtained as a dark brown powder by recrystallization from a $\mathrm{CH}_{2} \mathrm{Cl}_{2}$ /diethyl ether solution and dried in vacuo. Yield: $51 \mathrm{mg}(99 \%)$. MS(ESI): $\mathrm{m} / z$ : 407.0 $\left([\mathrm{M}]^{3+}\right.$, Calc. 407.04). Anal. Calc. for $\mathrm{C}_{64} \mathrm{H}_{42} \mathrm{~B}_{3} \mathrm{ClF}_{12} \mathrm{~N}_{10} \mathrm{O}_{2} \mathrm{Ru}_{2}$ (1481.1):C 51.90, H 2.86, N 9.46; found C 51.70, H 2.77, N 9.34 .

\subsection{Water Oxidation}

An aqueous solution $(5 \mathrm{~mL})$ of $\left(\mathrm{NH}_{4}\right)_{2}\left[\mathrm{Ce}\left(\mathrm{NO}_{3}\right)_{6}\right](548 \mathrm{mg}, 1.00 \mathrm{mmol})$ at $\mathrm{pH}$ 1.0, adjusted with $\mathrm{HNO}_{3}$, was added into a closed cell with a septum cap and an oxygen sensor. An Ar gas stream was passed through the solution for $15 \mathrm{~min}$. A 2,2,2-trifluoroethanol solution ( $300 \mu \mathrm{L})$ of the catalyst $(1.0 \mu \mathrm{mol})$ was added to the reaction cell. The concentration of oxygen in the gas layer was measured with an oxygen sensor. After the reaction, contamination of air was checked by GC-2014 (Shimazu Corp., Kyoto, Japan) with a molecular sieve 5A column.

\subsection{Measurements}

\subsubsection{Cyclic Voltammetry (CV) Measurements}

CVs of aqueous solutions at $\mathrm{pH} 1.3$ (adjusted with $\mathrm{HNO}_{3}$ ) containing $0.2 \mathrm{mmol} \cdot \mathrm{L}^{-1}$ of $[3]\left(\mathrm{BF}_{4}\right)_{3}$ and $100 \mathrm{mmol} \cdot \mathrm{L}^{-1}$ of $\mathrm{NaNO}_{3}$ as the electrolyte were measured at a scan rate of $50 \mathrm{mV} \cdot \mathrm{s}^{-1}$ at $298 \mathrm{~K}$ using plate material evaluating cell (ALS Corp. Ltd., Tokyo, Japan) with an indium-tin-oxide (ITO) glass plate as the working electrode, a Pt wire as the counter electrode, and a saturated calomel electrode (SCE) as the reference electrode. The diameter of ITO electrode surface in contact with liquid was $7.8 \mathrm{~mm}$. The test solutions were deoxygenated by passing a stream of Ar through them.

\subsubsection{UV-Vis Spectral Measurements with Controlled-Potential Electrolysis}

UV-vis spectral measurements with controlled-potential electrolysis were conducted with a UV cell (pass length $=10 \mathrm{~mm}$ ) attached to an ITO electrode as the working electrode and a sample holder (ALS Co., Ltd.) containing SCE and Pt wire as the reference and counter electrodes, respectively. An aqueous solution at $\mathrm{pH} 1.3$ (adjusted with $\mathrm{HNO}_{3}$ ) containing [3] $\left(\mathrm{BF}_{4}\right)_{3}$ and $\mathrm{NaNO}_{3}\left(100 \mathrm{mmol} \cdot \mathrm{L}^{-1}\right)$ was added to the optical cell and electrolyzed at different potentials. Spectral changes in the solution were observed by UV-vis spectral measurements.

\subsubsection{Raman Spectral Measurements with Controlled-Potential Electrolysis}

Electrolysis of $\mathrm{H}_{2}{ }^{16} \mathrm{O}$ and $\mathrm{H}_{2}{ }^{18} \mathrm{O}$ solutions at $\mathrm{pH} 1.0$ (adjusted with $\mathrm{HNO}_{3}$ ) containing $0.2 \mathrm{~mol} \cdot \mathrm{dm}^{-3}$ of $[3]\left(\mathrm{BF}_{4}\right)_{3}$ was conducted with a plate material evaluating cell (ALS Co., Ltd.) containing ITO as the working electrode and a sample holder (ALS Co., Ltd.) containing SCE and Pt wire as the reference and counter electrodes, respectively. After electrolysis of the solution at $+1.6 \mathrm{~V}$, the solution color changed from dark purple to dark green. Raman spectra of the dark green solutions were recorded at room temperature.

\subsubsection{Raman Spectral Measurements of the Chemically Oxidized Species}

Resonance Raman spectra of the chemically oxidized form of [2](BF $\mathrm{BF}_{3}$ were recorded as follows. $\left(\mathrm{NH}_{4}\right)_{2}\left[\mathrm{Ce}\left(\mathrm{NO}_{3}\right)_{6}\right](2.7 \mathrm{mg}, 4.9 \mu \mathrm{mol})$ was added to a solution of [3] $\left(\mathrm{BF}_{4}\right)_{3}(1.0 \mathrm{mg}, 0.68 \mu \mathrm{mol})$ in $\mathrm{H}_{2}{ }^{16} \mathrm{O}$ and $\mathrm{H}_{2}{ }^{18} \mathrm{O}(500 \mu \mathrm{L})$ at $\mathrm{pH} 1.0$, adjusted with $\mathrm{HNO}_{3}$. Resonance Raman spectra of the solutions were recorded at room temperature. 


\subsubsection{X-ray Crystallography}

Single crystals of btpyaq were obtained by slow evaporation of a benzene solution of btpyan in a fume hood. A summary of the crystal structure refinements of btpyaq is given in Table S1. Data were collected on a Bruker D8 Quest CMOS diffractometer (Bruker Corp., Blerica, MA, USA) using graphite-monochromated MoK $\alpha$ radiation $(\lambda=0.71070 \AA)$ at $90 \mathrm{~K}$, and processed with a Bruker APEX2 software package [69] using SHELXL-2014 [70] except for the refinement. Absorption corrections were made using the multiscan technique. The structure was solved applying Olex2 [71] with the olex2.solve [72] structure solution program using charge flipping and refined with the olex2.refine [72] refinement package using Gauss-Newton minimization. All non-hydrogen atoms were refined anisotropically. All hydrogen atoms were refined isotropically, and a rigid model was employed during refinement of the hydrogen atom positions; the hydrogen atoms on the carbon atoms were fixed at calculated distances (i.e., $d_{\mathrm{CH}}=0.97 \AA$ ). Crystallographic data for the structural analysis of btpynq. $\mathrm{C}_{6} \mathrm{H}_{6}$ were deposited with the Cambridge Crystallographic Data Centre. CCDC-1524361 contains the supplementary crystallographic data for this paper. These data can be obtained free of charge from the Cambridge Crystallographic Data Centre via www.ccdc.cam.ac.uk/data_request/cif.

\section{Conclusions}

We successfully demonstrated the dinuclear Ruthenium complex [3]( $\left.\mathrm{BF}_{4}\right)_{3}$ bridged by 1,8-bis(terpyridyl)anthraquinone (btpyaq) as a new dimerizing ligand that catalyzes water oxidation to oxygen with $\left(\mathrm{NH}_{4}\right)_{2}\left[\mathrm{Ce}\left(\mathrm{NO}_{3}\right)_{6}\right]$ as the oxidant. $\mathrm{CVs}$ and UV-vis and Raman spectra with controlled-potential electrolysis revealed that $[\mathrm{Ru}(\mathrm{IV})=\mathrm{O} \mathrm{O}=\mathrm{Ru}(\mathrm{IV})]^{4+}$ is stable under electrolysis conditions at $+1.40 \mathrm{~V}$, and that the $[\mathrm{Ru}(\mathrm{III}), \mathrm{Ru}(\mathrm{II})]$ species is recovered by dissociation of an $\mathrm{O}_{2}$ molecule from the active species in the catalytic cycle. These results clearly indicate that an $\mathrm{O}-\mathrm{O}$ bond is formed via $[\mathrm{Ru}(\mathrm{IV})=\mathrm{O} O=\mathrm{Ru}(\mathrm{V})]^{5+}$. It is worth noting that the oxidation number of the active species in the catalytic cycle has been identified, as the generation of active species at a relatively negative potential is crucial to develop catalysts for water oxidation with a small overpotential.

Supplementary Materials: The following are available online at www.mdpi.com/2073-4344/7/2/56/s1, Table S1: Crystallographic data for btpyaq. $\mathrm{C}_{6} \mathrm{H}_{6}$, Figure S1: Cyclic voltammogram of [3] $\left(\mathrm{BF}_{4}\right)_{3}$ in $\mathrm{CF}_{3} \mathrm{CH}_{2} \mathrm{OH}$ solution, Figure S2: Cyclic voltammogram of $[3]\left(\mathrm{BF}_{4}\right)_{3}$ in the solution at $\mathrm{pH} 1.3$ after electrolysis of the solution at $1.60 \mathrm{~V}$.

Acknowledgments: This work was financially supported by a Grant-in-Aid for Scientific Research on Innovative Areas (No. 15H00884), the Supported Program for the Strategic Research Foundation at Private Universities, 2013-2018 from The Ministry of Education, Culture, Sports, Science and Technology, and Rikkyo University Special Fund for Research.

Author Contributions: T.M. and T.A. synthesized btpyaq; S.N. synthesized dinuclear Ruthenium complexes and performed the catalytic reactions and electrochemical experiments; T.W. wrote the paper; and Y.M. contributed with the analysis tools and also corrected the initial draft of the manuscript.

Conflicts of Interest: The authors declare no conflict of interest.

\section{References}

1. Zhou, H.; Yan, R.; Zhang, D.; Fan, T. Challenges and perspectives in designing artificial photosynthetic systems. Chem. Eur. J. 2016, 22, 9870-9885. [CrossRef] [PubMed]

2. Yamazaki, Y.; Takeda, H.; Ishitani, O. Photocatalytic reduction of $\mathrm{CO}_{2}$ using metal complexes. J. Photochem. Photobiol. C Photochem. Rev. 2015, 25, 106-137. [CrossRef]

3. Soman, S. Molecular systems for solar H2: Path to a renewable future. Comment Inorg. Chem. 2015, 35, 82-120. [CrossRef]

4. House, R.L.; Tha, N.Y.M.; Coppo, R.L.; Alibabaei, L.; Sherman, B.D.; Kang, P.; Brennaman, M.K.; Hoertz, P.G.; Meyer, T.J. Artificial photosynthesis. J. Photochem. Photobiol. C Photochem. Rev. 2015, 25, 32-45. [CrossRef]

5. Fukuzumi, S. Artificial photosynthetic systems for production of hydrogen. Curr. Opin. Chem. Biol. 2015, 25, 18-26. [CrossRef] [PubMed] 
6. Fenwick, A.Q.; Gregoire, J.M.; Luca, O.R. Electrocatalytic reduction of nitrogen and carbon dioxide to chemical fuels: Challenges and opportunities for a solar fuel device. J. Photochem. Photobiol. B Biol. 2015, 152, 47-57. [CrossRef] [PubMed]

7. Nocera, D.G. The artificial leaf. Acc. Chem. Res. 2012, 45, 767-776. [CrossRef] [PubMed]

8. Song, W.; Chen, Z.; Brennaman, M.K.; Concepcion, J.J.; Patrocinio, A.O.T.; Iha, N.Y.M.; Meyer, T.J. Making solar fuels by artificial photosynthesis. Pure Appl. Chem. 2011, 83, 749-768. [CrossRef]

9. Cook, T.R.; Dogutan, D.K.; Reece, S.Y.; Surendranath, Y.; Teets, T.S.; Nocera, D.G. Solar energy supply and storage for the legacy and nonlegacy worlds. Chem. Rev. 2010, 110, 6474-6502. [CrossRef] [PubMed]

10. Nocera, D.G. Chemistry of personalized solar energy. Inorg. Chem. 2009, 48, 10001-10017. [CrossRef] [PubMed]

11. Inoue, H.; Shimada, T.; Kou, Y.; Nabetani, Y.; Masui, D.; Takagi, S.; Tachibana, H. The water oxidation bottleneck in artificial photosynthesis: How can we get through it? An alternative route involving a two-electron process. ChemSusChem 2011, 4, 173-179. [CrossRef] [PubMed]

12. Tong, L.; Thummel, R.P. Mononuclear Ruthenium polypyridine complexes that catalyze water oxidation. Chem. Sci. 2016, 7, 6591-6603. [CrossRef]

13. Xue, L.-X.; Meng, T.-T.; Yang, W.; Wang, K.-Z. Recent advances in Ruthenium complex-based light-driven water oxidation catalysts. J. Photochem. Photobiol. B Biol. 2015, 152, 95-105. [CrossRef] [PubMed]

14. Wu, X.; Li, F.; Zhang, B.; Sun, L. Molecular complexes in water oxidation: Pre-catalysts or real catalysts. J. Photochem. Photobiol. C Photochem. Rev. 2015, 25, 71-89. [CrossRef]

15. Duan, L.; Wang, L.; Li, F.; Li, F.; Sun, L. Highly fficient bioinspired molecules Ru water oxidation. Catalysts with negatively Charged backbone ligands. Acc. Chem. Res. 2015, 48, 2084-2096. [CrossRef] [PubMed]

16. Blakemore, J.D.; Crabtree, R.H.; Brudvig, G.W. Molecular catalysts for water oxidation. Chem. Rev. 2015, 115, 12947-13005. [CrossRef] [PubMed]

17. Kaerkaes, M.D.; Verho, O.; Johnston, E.V.; Aakermark, B. Artificial photosynthesis: Molecular systems for catalytic water oxidation. Chem. Rev. 2014, 114, 11863-12001. [CrossRef] [PubMed]

18. Kaerkaes, M.D.; Johnston, E.V.; Verho, O.; Aakermark, B. Artificial photosynthesis: From nanosecond electron transfer to catalytic water oxidation. Acc. Chem. Res. 2014, 47, 100-111. [CrossRef] [PubMed]

19. Hirahara, M.; Shoji, A.; Yagi, M. Artificial manganese center models for photosynthetic oxygen evolution in photosystem II. Eur. J. Inorg. Chem. 2014, 2014, 595-606. [CrossRef]

20. Francas, L.; Bofill, R.; Garcia-Anton, J.; Escriche, L.; Sala, X.; Llobet, A. Ru-based water oxidation catalysts. Mol. Water Oxid. Catal. 2014, 29-50. [CrossRef]

21. Wasylenko, D.J.; Palmer, R.D.; Berlinguette, C.P. Homogeneous water oxidation catalysts containing a single metal site. Chem. Commun. 2013, 49, 218-227. [CrossRef] [PubMed]

22. McAlpin, J.G.; Stich, T.A.; Casey, W.H.; Britt, R.D. Comparison of cobalt and manganese in the chemistry of water oxidation. Coord. Chem. Rev. 2012, 256, 2445-2452. [CrossRef]

23. Artero, V.; Chavarot-Kerlidou, M.; Fontecave, M. Splitting water with cobalt. Angew. Chem. Int. Ed. 2011, 50, 7238-7266. [CrossRef] [PubMed]

24. Yagi, M.; Syouji, A.; Yamada, S.; Komi, M.; Yamazaki, H.; Tajima, S. Molecular catalysts for water oxidation toward artificial photosynthesis. Photochem. Photobiol. Sci. 2009, 8, 139-147. [CrossRef]

25. Yagi, M.; Kaneko, M. Molecular catalysts for water oxidation. Chem. Rev. 2001, 101, 21-35. [CrossRef] [PubMed]

26. Okada, T.; Abe, T.; Kaneko, M. Historical overview and fundamental aspects of molecular catalysts for energy conversion. In Molecular Catalysts for Energy Conversion; Springer Series in Materials Science; Springer: Berlin/Heidelberg, Germany, 2009; Volume 111, pp. 1-36.

27. Ruettinger, W.; Dismukes, G.C. Synthetic water-oxidation catalysts for artificial photosynthetic water oxidation. Chem. Rev. 1997, 97, 1-24. [CrossRef]

28. Geletii Yurii, V.; Botar, B.; Kogerler, P.; Hillesheim Daniel, A.; Musaev Djamaladdin, G.; Hill Craig, L. An all-inorganic, stable, and highly active tetraRuthenium homogeneous catalyst for water oxidation. Angew. Chem. Int. Ed. 2008, 47, 3896-3899. [CrossRef] [PubMed]

29. Sartorel, A.; Carraro, M.; Scorrano, G.; de Zorzi, R.; Geremia, S.; McDaniel, N.D.; Bernhard, S.; Bonchio, M. Polyoxometalate embedding of a tetraRuthenium(iv)-oxo-core by template-directed metalation of $\left[\gamma-\mathrm{SiW}_{10} \mathrm{O}_{36}\right]^{8-}$ : A totally inorganic oxygen-evolving catalyst. J. Am. Chem. Soc. 2008, 130, 5006-5007. [CrossRef] [PubMed] 
30. Zeng, Q.; Lewis, F.W.; Harwood, L.M.; Hartl, F. Role of ligands in catalytic water oxidation by mononuclear Ruthenium complexes. Coord. Chem. Rev. 2015, 304-305, 88-101. [CrossRef]

31. Sala, X.; Maji, S.; Bofill, R.; Garcia-Anton, J.; Escriche, L.; Llobet, A. Molecular water oxidation mechanisms followed by transition metals: State of the art. Acc. Chem. Res. 2014, 47, 504-516. [CrossRef] [PubMed]

32. Kikuchi, T.; Tanaka, K. Mechanistic approaches to molecular catalysts for water oxidation. Eur. J. Inorg. Chem. 2014, 2014, 607-618. [CrossRef]

33. Sala, X.; Romero, I.; Rodriguez, M.; Escriche, L.; Llobet, A. Molecular catalysts that oxidize water to dioxygen. Angew. Chem. Int. Ed. 2009, 48, 2842-2852. [CrossRef] [PubMed]

34. Betley, T.A.; Wu, Q.; van Voorhis, T.; Nocera, D.G. Electronic design criteria for O-O bond formation via metal-oxo complexes. Inorg. Chem. 2008, 47, 1849-1861. [CrossRef] [PubMed]

35. Gagliardi, C.J.; Vannucci, A.K.; Concepcion, J.J.; Chen, Z.; Meyer, T.J. The role of proton coupled electron transfer in water oxidation. Energy Environ. Sci. 2012, 5, 7704-7717. [CrossRef]

36. Meyer, T.J.; Huynh, M.H.V.; Thorp, H.H. The possible role of proton-coupled electron transfer (PCET) in water oxidation by photosystem II. Angew. Chem. Int. Ed. 2007, 46, 5284-5304. [CrossRef] [PubMed]

37. Huynh, M.H.V.; Meyer, T.J. Proton-coupled electron transfer. Chem. Rev. 2007, 107, 5004-5064. [CrossRef] [PubMed]

38. Meyer, T.J.; Huynh, M.H.V. The remarkable reactivity of high oxidation state Ruthenium and osmium polypyridyl complexes. Inorg. Chem. 2003, 42, 8140-8160. [CrossRef] [PubMed]

39. Lebeau, E.L.; Binstead, R.A.; Meyer, T.J. Mechanistic implications of proton transfer coupled to electron transfer. J. Am. Chem. Soc. 2001, 123, 10535-10544. [CrossRef] [PubMed]

40. Concepcion, J.J.; Tsai, K.; Muckerman, J.T.; Meyer, T.J. Mechanism of water oxidation by single-site Ruthenium complex catalysts. J. Am. Chem. Soc. 2010, 132, 1545-1557. [CrossRef] [PubMed]

41. Badiei, Y.M.; Polyansky, D.E.; Muckerman, J.T.; Szalda, D.J.; Haberdar, R.; Zong, R.; Thummel, R.P.; Fujita, E. Water oxidation with mononuclear Ruthenium(II) polypyridine complexes involving a direct $\mathrm{Ru}(\mathrm{IV})=\mathrm{O}$ pathway in neutral and alkaline media. Inorg. Chem. 2013, 52, 8845-8850. [CrossRef] [PubMed]

42. Romain, S.; Bozoglian, F.; Sala, X.; Llobet, A. Oxygen-oxygen bond formation by the Ru-Hbpp water oxidation catalyst occurs solely via an intramolecular reaction pathway. J. Am. Chem. Soc. 2009, 131, 2768-2769. [CrossRef] [PubMed]

43. Wang, L.; Duan, L.; Wang, Y.; Ahlquist, M.S.G.; Sun, L. Highly efficient and robust molecular water oxidation catalysts based on Ruthenium complexes. Chem. Commun. 2014, 50, 12947-12950. [CrossRef] [PubMed]

44. Duan, L.; Bozoglian, F.; Mandal, S.; Stewart, B.; Privalov, T.; Llobet, A.; Sun, L. A molecular Ruthenium catalyst with water-oxidation activity comparable to that of photosystem II. Nat. Chem. 2012, 4, 418-423. [CrossRef] [PubMed]

45. Duan, L.; Wang, L.; Inge, A.K.; Fischer, A.; Zou, X.; Sun, L. Insights into ru-based molecular water oxidation catalysts: Electronic and noncovalent-interaction effects on their catalytic activities. Inorg. Chem. 2013, 52, 7844-7852. [CrossRef] [PubMed]

46. Shimoyama, Y.; Ishizuka, T.; Kotani, H.; Shiota, Y.; Yoshizawa, K.; Mieda, K.; Ogura, T.; Okajima, T.; Nozawa, S.; Kojima, T. A Ruthenium(III)-oxyl complex bearing strong radical character. Angew. Chem. Int. Ed. 2016, 55, 14041-14045. [CrossRef] [PubMed]

47. Stull, J.A.; Stich, T.A.; Hurst, J.K.; Britt, R.D. Electron paramagnetic resonance analysis of a transient species formed during water oxidation catalyzed by the complex ion $\left[(\text { bpy })_{2} \mathrm{Ru}\left(\mathrm{OH}_{2}\right)\right]_{2} \mathrm{O}^{4+}$. Inorg. Chem. 2013, 52, 4578-4586. [CrossRef] [PubMed]

48. Wada, T.; Hiraide, T.; Miyazato, Y. Water oxidation catalyzed by a Ruthenium complex with an Ru-C bond. ChemistrySelect 2016, 1, 3045-3048. [CrossRef]

49. Wada, T.; Tanaka, K.; Muckerman, J.T.; Fujita, E. Water oxidation by Ruthenium catalysts with non-innocent ligands. In Moecular Water Oxidation Catalysis, 1st ed.; Llobet, A., Ed.; John Wiley \& Sons, Ltd.: Chichester, UK, 2014; pp. 77-111.

50. Wada, T.; Ohtsu, H.; Tanaka, K. Catalytic four-electron oxidation of water by intramolecular coupling of the oxo ligands of a bis(Ruthenium-bipyridine) complex. Chem. Eur. J. 2012, 18, 2374-2381. [CrossRef] [PubMed]

51. Wada, T.; Muckerman, J.T.; Fujita, E.; Tanaka, K. Substituents dependent capability of bis(Rutheniumdioxolene-terpyridine) complexes toward water oxidation. Dalton Trans. 2011, 40, 2225-2233. [CrossRef] [PubMed] 
52. Muckerman, J.T.; Polyansky, D.E.; Wada, T.; Tanaka, K.; Fujita, E. Water oxidation by a Ruthenium complex with noninnocent quinone ligands: Possible formation of an $\mathrm{O}-\mathrm{O}$ bond at a low oxidation state of the metal. Inorg. Chem. 2008, 47, 1787-1802. [CrossRef] [PubMed]

53. Wada, T.; Tsuge, K.; Tanaka, K. Syntheses and redox properties of bis(hydroxoRuthenium) complexes with quinone and bipyridine ligands. Water-oxidation catalysis. Inorg. Chem. 2001, 40, 329-337. [CrossRef] [PubMed]

54. Wada, T.; Tsuge, K.; Tanaka, K. Electrochemical oxidation of water to dioxygen catalyzed by the oxidized form of the bis(Ruthenium-hydroxo) complex in $\mathrm{H}_{2}$ O. Angew. Chem. Int. Ed. 2000, 39, 1479-1482. [CrossRef]

55. Isobe, H.; Tanaka, K.; Shen, J.-R.; Yamaguchi, K. Water oxidation chemistry of a synthetic dinuclear Ruthenium complex containing redox-active quinone ligands. Inorg. Chem. 2014, 53, 3973-3984. [CrossRef] [PubMed]

56. Yamaguchi, K.; Yamanaka, S.; Isobe, H.; Tanaka, K.; Ueyama, N. Spin hamiltonian models for artificial and native water splitting systems revealed by hybrid dft calculations. Oxygen activation by high-valent $\mathrm{mn}$ and Ru ions. Int. J. Quantum Chem. 2012, 112, 3849-3866. [CrossRef]

57. Tanaka, K.; Isobe, H.; Yamanaka, S.; Yamaguchi, K. Similarities of artificial photosystems by Ruthenium oxo complexes and native water splitting systems. Proc. Natl. Acad. Sci. USA 2012, 109, 15600-15605. [CrossRef] [PubMed]

58. Ghosh, S.; Baik, M.-H. Redox properties of tanaka's water oxidation catalyst: Redox noninnocent ligands dominate the electronic structure and reactivity. Inorg. Chem. 2011, 50, 5946-5957. [CrossRef] [PubMed]

59. Yoshida, M.; Masaoka, S. Cerium(IV)-driven oxidation of water catalyzed by mononuclear Ruthenium complexes. Res. Chem. Int. 2014, 40, 3169-3182. [CrossRef]

60. Kimoto, A.; Yamauchi, K.; Yoshida, M.; Masaoka, S.; Sakai, K. Kinetics and dft studies on water oxidation by $\mathrm{Ce}^{4+}$ catalyzed by $\left[\mathrm{Ru}(\text { terpy })(\text { bpy })\left(\mathrm{OH}_{2}\right)\right]^{2+}$. Chem. Commun. 2012, 48, 239-241. [CrossRef] [PubMed]

61. Yoshida, M.; Masaoka, S.; Abe, J.; Sakai, K. Catalysis of mononuclear aquaRuthenium complexes in oxygen evolution from water: A new radical coupling path using hydroxocerium(IV) species. Chem. Asian J. 2010, 5, 2369-2378. [CrossRef] [PubMed]

62. Yamada, H.; Koike, T.; Hurst, J.K. Water exchange rates in the diRuthenium $\mu$-oxo ion cis,cis-[(bpy) $\left.{ }_{2} \mathrm{Ru}\left(\mathrm{OH}_{2}\right)\right]_{2} \mathrm{O}^{4+}$. J. Am. Chem. Soc. 2001, 123, 12775-12780. [CrossRef] [PubMed]

63. Moonshiram, D.; Purohit, V.; Concepcion, J.J.; Meyer, T.J.; Pushkar, Y. Mechanism of catalytic water oxidation by the Ruthenium blue dimer catalyst: Comparative study in $\mathrm{D}_{2} \mathrm{O}$ versus $\mathrm{H}_{2} \mathrm{O}$. Materials 2013, 6, $392-409$. [CrossRef]

64. Liu, F.; Concepcion, J.J.; Jurss, J.W.; Cardolaccia, T.; Templeton, J.L.; Meyer, T.J. Mechanisms of water oxidation from the blue dimer to photosystem II. Inorg. Chem. 2008, 47, 1727-1752. [CrossRef] [PubMed]

65. Binstead, R.A.; Chronister, C.W.; Ni, J.; Hartshorn, C.M.; Meyer, T.J. Mechanism of water oxidation by the $\mu$-oxo dimer $\left[(\text { bpy })_{2}\left(\mathrm{H}_{2} \mathrm{O}\right) \mathrm{Ru}^{\mathrm{III}} \mathrm{ORu}{ }^{\mathrm{III}}\left(\mathrm{OH}_{2}\right)(\mathrm{bpy})_{2}\right]^{4+}$. J. Am. Chem. Soc. 2000, 122, 8464-8473. [CrossRef]

66. Chronister, C.W.; Binstead, R.A.; Ni, J.; Meyer, T.J. Mechanism of water oxidation catalyzed by the $\mu$-oxo dimer $\left[(\text { bpy })_{2}\left(\mathrm{H}_{2} \mathrm{O}\right) \mathrm{Ru}^{\mathrm{III}} \mathrm{ORu}{ }^{\mathrm{III}}\left(\mathrm{OH}_{2}\right)(\text { bpy })_{2}\right]^{4+}$. Inorg. Chem. 1997, 36, 3814-3815. [CrossRef]

67. Ukai, T.; Kawazura, H.; Ishii, Y.; Bonnet, J.J.; Ibers, J.A. Chemistry of dibenzylideneacetone-palladium(0) complexes. I. Novel tris(dibenzylideneacetone)dipalladium(solvent) complexes and their reactions with quinones. J. Organomet. Chem. 1974, 65, 253-266. [CrossRef]

68. Potts, K.T.; Konwar, D. Synthesis of $4^{\prime}$-vinyl-2,2' $: 6^{\prime}, 2^{\prime \prime}$-terpyridine. J. Org. Chem. 1991, 56, 4815-4816. [CrossRef]

69. APEX2, ver2014.11-0. Bruker-AXS: Madison, WI, USA, 2014.

70. Sheldrick, G.M. A short history of SHELX. Acta Crystallogr. Sect. A 2008, 64, 112-122. [CrossRef] [PubMed]

71. Dolomanov, O.V.; Bourhis, L.J.; Gildea, R.J.; Howard, J.A.K.; Puschmann, H. OLEX2: A complete structure solution, refinement and analysis program. J. Appl. Cryst. 2009, 42, 339-341. [CrossRef]

72. Bourhis, L.J.; Dolomanov, O.V.; Gildea, R.J.; Howard, J.A.K.; Puschmann, H. The anatomy of a comprehensive constrained, restrained refinement program for the modern computing environment-Olex2 dissected. Acta Cryst. 2015, A71, 59-75.

(C) 2017 by the authors; licensee MDPI, Basel, Switzerland. This article is an open access article distributed under the terms and conditions of the Creative Commons Attribution (CC BY) license (http:/ / creativecommons.org/licenses/by/4.0/). 